\title{
The roles of convection, extratropical mixing, and in-situ freeze-drying in the Tropical Tropopause Layer
}

\author{
W. G. Read ${ }^{1}$, M. J. Schwartz ${ }^{1}$, A. Lambert ${ }^{1}$, H. Su${ }^{1}$, N. J. Livesey ${ }^{1}$, W. H. Daffer ${ }^{1}$, and C. D. Boone ${ }^{2}$ \\ ${ }^{1}$ Jet Propulsion Laboratory, California Institute of Technology, Pasadena, CA, USA \\ ${ }^{2}$ Department of Chemistry, University of Waterloo, Ontario, Canada
}

Received: 14 December 2007 - Published in Atmos. Chem. Phys. Discuss.: 26 February 2008

Revised: 2 June 2008 - Accepted: 29 August 2008 - Published: 21 October 2008

\begin{abstract}
Mechanisms for transporting and dehydrating air across the tropical tropopause layer (TTL) are investigated with a conceptual two dimensional (2-D) model. The 2-D TTL model combines the Holton and Gettelman cold trap dehydration mechanism (Holton and Gettelman, 2001) with the two column convection model of Folkins and Martin (2005). We investigate 3 possible transport scenarios through the TTL: 1) slow uniform ascent across the level of zero radiative heating without direct convective mixing, 2) convective mixing of $\mathrm{H}_{2} \mathrm{O}$ vapor at $100 \%$ relative humidity with respect to ice (RHi) with no ice retention, and 3) convective mixing of extremely subsaturated air (100\% RHi following the moist adiabatic temperature above the level of neutral buoyancy) with sufficient ice retention such that total $\mathrm{H}_{2} \mathrm{O}$ is $100 \%$ RHi. The three mechanisms produce similar seasonal cycles for $\mathrm{H}_{2} \mathrm{O}$ that are in good quantitative agreement with the Aura Microwave Limb Sounder (MLS) measurements. We use Aura MLS measurement of CO and Atmospheric Chemistry Experiment-Fourier Transform Spectrometer measurement of HDO to distinguish among the transport mechanisms. Model comparisons with the observations support the view that $\mathrm{H}_{2} \mathrm{O}$ is predominantly controlled by regions having the lowest cold point tropopause temperature but the trace species CO and HDO support the convective mixing of dry air and lofted ice. The model provides some insight into the processes affecting the long term trends observed in stratospheric $\mathrm{H}_{2} \mathrm{O}$.
\end{abstract}

\section{Introduction}

Water vapor enters the stratosphere in the tropics (Brewer, 1949; Holton et al., 1995) through convective injection and

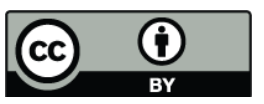

Correspondence to: W. G. Read (bill@mls.jpl.nasa.gov) diabatic ascent. Of particular interest is the long term trend in stratospheric $\mathrm{H}_{2} \mathrm{O}$. During the last half century stratospheric $\mathrm{H}_{2} \mathrm{O}$ has been steadily rising, potentially at twice the rate that can be explained from oxidation due to rising methane (Rosenlof et al., 2001). Recent reanalysis of some of the historical data suggest that the rising trend in $\mathrm{H}_{2} \mathrm{O}$ is $40 \%$ less than determined from the earlier analysis (Scherer et al., 2008). After 2000, water vapor showed a sharp decrease (Fueglistaler and Haynes, 2005; Nedoluha et al., 2003; Randel et al., 2006; Rosenlof and Reid, 2008). Dehydration and transport mechanisms that operate near the tropical tropopause, augmented by $\mathrm{CH}_{4}$ oxidation are believed to have significant roles in these trends. Much progress has been made recently in our understanding of how air is dehydrated. Models incorporating large scale horizontal transport through cold traps do an excellent job of reproducing the observed seasonal cycle of tropical $\mathrm{H}_{2} \mathrm{O}$ entering the stratosphere (Hartmann et al., 2001; Holton and Gettelman, 2001; Jensen et al., 2001; Gettelman et al., 2002; Bonazzola and Haynes, 2004; Fueglistaler et al., 2004; Jensen and Pfister, 2004; Fueglistaler et al., 2005; Fueglistaler and Haynes, 2005; Randel et al., 2006). An alternative hypothesis proposing dehydration of $\mathrm{H}_{2} \mathrm{O}$ by convective mixing of extremely subsaturated air (Sherwood and Dessler, 2001, 2003; Danielsen, 1982, 1993) was shown to be inconsistent with the vertical structure of Upper Atmosphere Research Satellite Microwave Limb Sounder (MLS) $\mathrm{H}_{2} \mathrm{O}$ between the upper troposphere and the tropopause (Read et al., 2004) and the variability observed in the isotopologues of $\mathrm{H}_{2} \mathrm{O}$ (Webster and Heymsfield, 2003). Studies using cloud resolving models show that while convection can inject dry air, condensed ice is not removed quickly enough to produce net dehydration (Grosvenor et al., 2007; Jensen et al., 2007; Smith et al., 2006).

Although a convective signature is not prevalent in $\mathrm{H}_{2} \mathrm{O}$ or needed to explain either its annual oscillation (Mote et al., 1996) or its stratospheric entry concentration (e.g.,

Published by Copernicus Publications on behalf of the European Geosciences Union. 


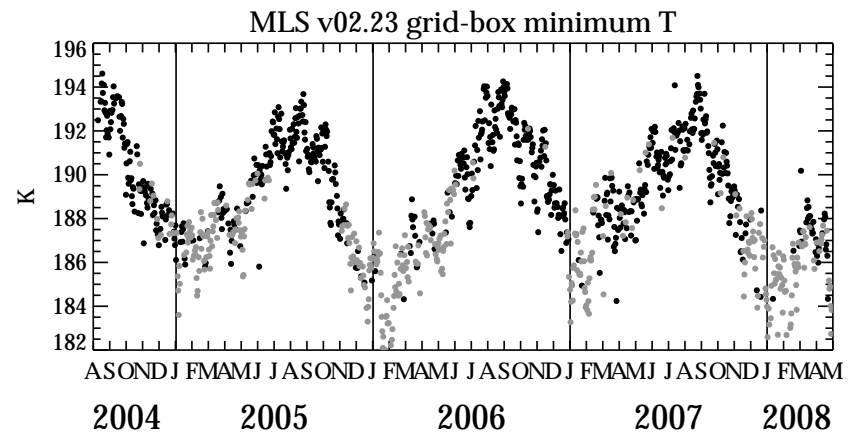

Fig. 1. MLS daily $12^{\circ}$ longitude bin-averaged minimum cold point tropopause temperature between $12^{\circ} \mathrm{S}-12^{\circ} \mathrm{N}$. The height of the $\mathrm{CPT}$ is indicated by color, gray is $83 \mathrm{hPa}$ and black is $100 \mathrm{hPa}$.

Fueglistaler et al., 2005), observations of other tracers show evidence of convective influence. In addition, clear sky radiative heating calculations indicate that there is a transport barrier 1-2 km below the cold-point tropopause (CPT) in the tropics (Folkins et al., 1999). The transport barrier or level of zero radiative heating (LZH) is where air above rises and air below sinks. The existence of the LZH below the CPT makes the region in between unique, having both tropospheric and stratospheric behaviors and is usually known as the tropical tropopause layer (TTL, Sherwood and Dessler, 2000). Observations of $\mathrm{CO}_{2}$ (Andrews et al., 1999) and CO (Schoeberl et al., 2006) have seasonal cycles at the tropopause that are present in these molecules in the boundary layer. As explained by Sherwood and Dessler (2003); Folkins et al. (2006b); Schoeberl et al. (2006), convection is needed to transport boundary layer air across the clear-sky LZH into the TTL.

Observations of the heavy isotopologues of $\mathrm{H}_{2} \mathrm{O}$, HDO and $\mathrm{H}_{2}^{18} \mathrm{O}$ show concentrations that are significantly higher than expected from a pure temperature controlled freezedrying process (Moyer et al., 1996; Johnson et al., 2001a; Kuang et al., 2003). It has been postulated that evaporation of convectively lofted ice (Moyer et al., 1996) provides the additional $\mathrm{HDO}$ and $\mathrm{H}_{2}^{18} \mathrm{O}$. Evidence of ice lofting and in situ freeze-drying was observed from aircraft (Webster and Heymsfield, 2003) in subtropical convection. Several studies employing different mechanisms have successfully reproduced observations of HDO (Dessler and Sherwood, 2003; Gettelman and Webster, 2005; Schmidt et al., 2005; Dessler et al., 2007); however, none of these models incorporate both in situ freeze-drying and convective mixing of dry air and lofted ice as suggested by cloud resolving models. Here we present a conceptual model that incorporates both in situ freeze drying and convective mixing. We run the model using 3 different representations of convection and transport across the TTL. The representation where convection detrains ice, subsaturated air (relative to the environment), and tropospheric $\mathrm{CO}$ successfully reproduces the tropical zonal mean observations of $\mathrm{H}_{2} \mathrm{O}, \mathrm{CO}$, and $\mathrm{HDO}$.

\section{TTL model description}

The TTL model used here is based upon the two dimensional (2-D) conceptual model developed by Holton and Gettelman (2001, herein after referred to as HG01). The model includes a parametrization for convective mixing (Folkins and Martin, 2005) and computes vapor and ice mixing ratios of $\mathrm{H}_{2} \mathrm{O}$, $\mathrm{HDO}$ and $\mathrm{H}_{2}^{18} \mathrm{O}$, and the mixing ratio of $\mathrm{CO}$. The model is a 2-D representation (longitude by height) of the TTL. The vertical domain of the model covers $14-19 \mathrm{~km}$ and the horizontal domain is $40000 \mathrm{~km}$. The model has 61 vertical and 81 horizontal levels. The model uses daily v2.2 Aura MLS temperature averaged in $3012^{\circ}$ longitude bins between $12^{\circ} \mathrm{S}-$ $12^{\circ} \mathrm{N}$. The Aura MLS retrieves temperature in five levels between 14 and $19 \mathrm{~km}(147,121,100,83$, and $68 \mathrm{hPa})$. A height dependent bias is removed (according to Fig. 36 in Schwartz et al., 2008).

The temperature profiles are evenly spaced across the $40000 \mathrm{~km}$ (approximately representing $0^{\circ}-360^{\circ} \mathrm{E}$ longitude) horizontal domain. We define $16.5 \mathrm{~km}$ as $100 \mathrm{hPa}$ without seasonal variation and compute the pressures of the model grid from hydrostatic balance. Temperature of the model grid is obtained from linear interpolation from the 30 MLS profiles. Temperature profiles corresponding to the day of the model time step are used. If an MLS measurement is unavailable for the day of a model time step, temperature from the nearest available MLS day is used.

As in the HG01 model, air parcels are advected horizontally through the model domain and encounter and experience the full temperature variability as observed by Aura MLS. If a cloud-free parcel exceeds $160 \%$ relative humidity with respect to ice (RHi), or $100 \%$ RHi when cloud is present, some $\mathrm{H}_{2} \mathrm{O}$ condenses to make, or grow, a cloud. Cloud ice generally tends to sediment leading to irreversible dehydration. In the absence of other processes, the grid box having the minimum temperature has the greatest potential to regulate stratospheric entry $\mathrm{H}_{2} \mathrm{O}$. Figure 1 shows the daily grid box minimum temperature from Aura MLS (bias corrected). During the Northern Hemisphere winter, the cold point tropopause (CPT) occurs at $83 \mathrm{hPa}$; and during the Northern Hemisphere summer, the CPT drops to $100 \mathrm{hPa}$.

The TTL model includes no parametrization for gravity wave perturbations (Pfister et al., 2001; Jensen and Pfister, 2004; Potter and Holton, 1995). Since gravity wave features are present in the Aura MLS temperatures (Wu et al., 2006), the TTL model does not necessarily need an additional parametrization for them; however, some gravity waves remain unresolved by Aura MLS. Neglecting these waves in the absence of other simplifications may cause the model to overestimate $\mathrm{H}_{2} \mathrm{O}$ entering the stratosphere. Gettelman et al. (2002) show more dehydration with increased 
temperature variance. Quantifying this error is difficult because the magnitude of unresolved gravity waves is unknown and are compensated by random noise in the Aura MLS temperature measurement. A rough estimate of this effect is derived from applying a 7 day high-pass filter to the minimum Aura MLS CPT temperature time series. The resulting time series visually looks like random noise having a standard deviation of $0.5 \mathrm{~K}$. The sum of amplitudes of all waves having a period less than 7 days in the Jensen and Pfister (2004) model is $1 \mathrm{~K}$. Therefore the impact of gravity waves may be underestimated by $0.5 \mathrm{~K}$.

Vapor and ice are partitioned according to HG01 and Folkins et al. (2006b)

$$
\begin{aligned}
\frac{D[X]_{v}}{D t} & =-\frac{[X]_{v}-[X]_{v}^{\text {ex }}}{\tau_{\alpha}}+\frac{[X]_{i}}{\tau_{E}}-\frac{[X]_{v}-[X]_{s}}{\tau_{c}} \\
& -\frac{[X]_{v}-[X]_{v}^{\text {conv }}}{\tau_{d}}+P-L[X]_{v}, \\
\frac{D[X]_{i}}{D t} & =-\frac{[X]_{i}-[X]_{i}^{\text {ex }}}{\tau_{\alpha}}-\frac{[X]_{i}}{\tau_{E}}+\frac{[X]_{v}-[X]_{s}}{\tau_{c}} \\
& -\frac{[X]_{i}-[X]_{i}^{\text {conv }}}{\tau_{d}} .
\end{aligned}
$$

The right hand terms in Eq. (2) going from 1st to 6th describe extratropical mixing, evaporation, condensation, convective mixing, chemical production and loss. The subscripts $v, i$, and $s$, on concentration $[X]$ refer to vapor, condensed phase, and vapor over condensed phase. Superscript conv and ex refer to convective and extratropical concentrations respectively. A vertical diffusion term which is a part of the original HG01 model has been omitted because sensitivity tests show it has negligible effect on the results.

The extratropical mixing rate profile, $\tau_{\alpha}$ (30 days at $14 \mathrm{~km}$ and 580 days at $19 \mathrm{~km}$ ) is that used in $\mathrm{HGO1}$ which is derived from an analysis of the $\mathrm{H}_{2} \mathrm{O}$ tape recorder signal (Mote et al., 1998). The extratropical mixing ratios of $\mathrm{H}_{2} \mathrm{O}, \mathrm{CO}, \mathrm{HDO}$, and $\mathrm{H}_{2}^{18} \mathrm{O}$, are based on observations. The extratropical $\left[\mathrm{H}_{2} \mathrm{O}\right]_{v}^{\text {ex }}$ is handled similarly to temperature using daily Aura MLS v2.2 measurements averaged in $12^{\circ}$ longitude bins between $30^{\circ} \mathrm{S}-20^{\circ} \mathrm{S}$ and $20^{\circ} \mathrm{N}-30^{\circ} \mathrm{N}$ linearly interpolated to the TTL 2-D grid. Extratropical CO, also from v2.2 Aura MLS measurements, is a daily zonal mean between $30^{\circ} \mathrm{S}-20^{\circ} \mathrm{S}$ and $20^{\circ} \mathrm{N}-30^{\circ} \mathrm{N}$. The extratropical $\mathrm{H}_{2} \mathrm{O}$ and $\mathrm{CO}$ include seasonal variations caused by the Northern Hemisphere monsoons. The isotopologues are expressed as $\delta \mathrm{D}$ or $\delta^{18} \mathrm{O}(\%)=1000\left[\mathrm{R} \times\left(\mathrm{HDO}\right.\right.$ or $\left.\mathrm{H}_{2}^{18} \mathrm{O}\right) / \mathrm{H}_{2} \mathrm{O}$ 1) where $\mathrm{R}$ is ( $\mathrm{HDO}$ or $\left.\mathrm{H}_{2}^{18} \mathrm{O}\right) / \mathrm{H}_{2} \mathrm{O}$ in Vienna standard mean ocean water. For $\delta \mathrm{D}$ we use the average multiyear Atmospheric Chemistry Experiment-Fourier Transform Spectrometer (ACE-FTS, Bernath et al., 2005) $20^{\circ} \mathrm{N} / \mathrm{S}-30^{\circ} \mathrm{N} / \mathrm{S}$ measurement of $-614 \%$ o from $150-100 \mathrm{hPa}$. For $\delta^{18} \mathrm{O}$ we use $-128 \%$ from Johnson et al. (2001b). The extratropical $[X]_{i}^{\text {ex }}$ for all species is zero.

The convective detrainment (mixing) rate, $\tau_{d}$, is diagnosed from the prescribed large scale upwelling and extratropical

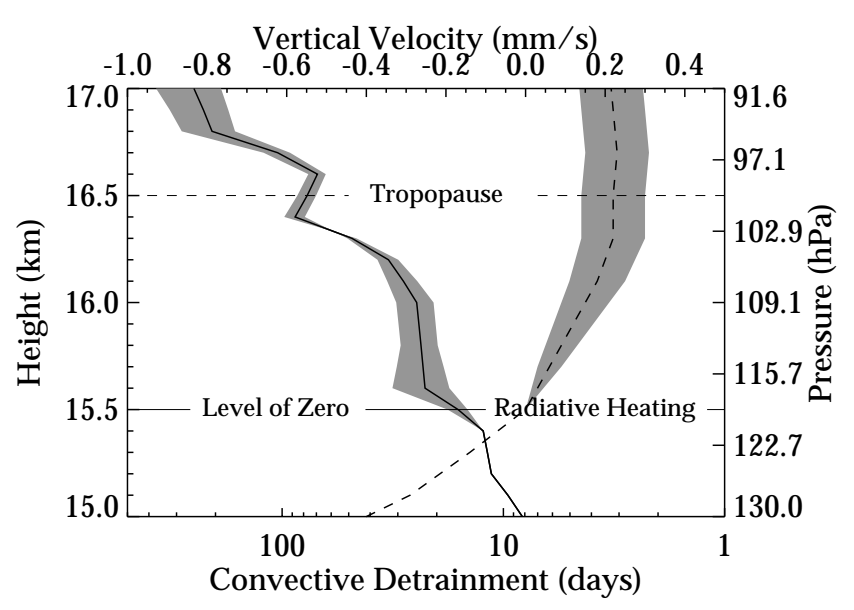

Fig. 2. Vertical velocities, dashed line, and convective mixing rates, solid line, used in the TTL model. The annual variations are shown by the shaded region about the mean profile. The Boreal summer shows slower upwelling velocities and longer detrainment rates.

mass flux divergence according to the two column model (TCM, Folkins and Martin, 2005). The upwelling and its seasonal cycle are derived from TCM results published in Folkins et al. (2006b, their Fig. 1, with the mass flux profiles shifted vertically to align their LZH with that used in the TTL model). The LZH is $15.5 \mathrm{~km}$ in the TTL model. The seasonal cycle for the upwelling is phased such that its maximum occurs on $14 \mathrm{Feb}$. The TCM calculations show that the maximum vertical velocity occurs $\sim 1 \mathrm{~km}$ above the LZH with a slight decline above.

Figure 2 shows the clear-sky vertical velocity with its annual oscillation. The prescribed velocity is consistent with other estimates (Mote et al., 1998; Randel et al., 2002; Andrews et al., 1999; Rosenlof, 1995). According to the TCM, the rate at which air detrains from the cloudy column is balanced by the radiative mass flux divergence of the clear sky column and the mass flux divergence to higher latitudes. Mathematically, $1 / \tau_{d}=\partial \omega / \partial p+1 / \tau_{\alpha}$, where $\omega$ is the radiative heating vertical mass flux which is proportional to the vertical velocity. The mass flux divergence to higher latitudes is the extratropical mixing rate from HG01. It is worth noting that the convective detrainment rate profile is not a free parameter in the TTL model. The seasonal variability of the computed convective detrainment rate profile is given in Fig. 2. Convective detrainment rates were diagnosed from $\mathrm{CO}$ and $\mathrm{O}_{3}$ profiles taken from the Feb. 1996 Stratospheric Tracers of Atmospheric Transport campaign (Dessler, 2002). The convective detrainment rate profile in Fig. 2 is shorter (faster) but within the uncertainty of that diagnosed from $\mathrm{O}_{3}$ and $\mathrm{CO}$ gradients up to the CPT. The convective supply terms, $[X]_{v}^{\text {conv }}$ and $[X]_{i}^{\text {conv }}$ whose values are most uncertain are discussed later. 
Downwelling of air associated with radiative cooling from subvisible cirrus lying above deep convective anvil clouds (Hartmann et al., 2001) which is included in the HG01 model is neglected in our TTL model because radiation calculations performed by Fueglistaler and Fu (2006) show this effect to be unimportant. Sensitivity tests with the TTL model also show that downwelling associated with thin cirrus has negligible effect on the results.

The time evolution of $[X]_{v}$ and $[X]_{i}$ is

$$
\frac{\partial[X]}{\partial t}=\frac{D[X]}{D t}-\omega \frac{\partial[X]}{\partial z}-u \frac{\partial[X]}{\partial x},
$$

where $\omega$ is the vertical velocity (different for gases and ice), $u$ is the horizontal velocity, $z$ is height, and $x$ is longitude. Equation 2 is solved using a semi-Lagrangian algorithm described in Staniforth and Côté (1991). The horizontal domain utilizes periodic boundary conditions. The horizontal velocity is $u=10 \mathrm{~m} / \mathrm{s}$ (HG01). Water vapor in the lowest altitude grid point is the v2.2 Aura MLS $147 \mathrm{hPa}$ tropical $12^{\circ}$ longitude bin averaged measurement corresponding to the day of the model time step interpolated to the model horizontal grid. Carbon monoxide is similar but uses the tropical zonal mean measurement from v2.2 Aura MLS observations. The heavy isotopologues use $\delta \mathrm{D}=-650 \%$ (from tropical ACEFTS measurements at $150 \mathrm{hPa}$ ) and $\delta^{18} \mathrm{O}=-154 \%$ (Webster and Heymsfield, 2003) for $\mathrm{HDO}$ and $\mathrm{H}_{2}^{18} \mathrm{O}$ respectively. These lower boundary conditions have no effect on the direct convective mixing cases because this level is below the LZH and sinks. The model is run from August 2003 to May 2008. The first year is used to spin-up the model and uses temperature and species data from August 2004 to July 2005 for the 2003/2004 period.

\section{$2.1 \quad \mathrm{H}_{2} \mathrm{O}$ modeling}

The evaporation and condensation rates, $\tau_{E}=1$ day, and $\tau_{c}=1 \mathrm{~h}$, are those used in HG01. Condensation, the 3rd term in Eq. (2), vanishes except when $\left[\mathrm{H}_{2} \mathrm{O}\right]_{v} \geq 100 \%$ RHi and $\left[\mathrm{H}_{2} \mathrm{O}\right]_{i}>0$ or $\left[\mathrm{H}_{2} \mathrm{O}\right]_{v} \geq 160 \%$ RHi and $\left[\mathrm{H}_{2} \mathrm{O}\right]_{i}=0$ (Jensen et al., 2001; Koop et al., 1998). Ice sediments at a velocity proportional to its effective radius according to a relation given in Boehm et al. (1999). The effective radius of the ice particles is parametrized according to their ice water content (IWC, Gettelman et al., 2002; McFarquhar and Heymsfield, 1997). The sedimentation rates are typically $\sim 7 \mathrm{~mm} / \mathrm{s}$ for $\sim 6.5 \mu$ m radius particles.

The production $P$, and loss $L$, terms are highly parametrized in this model. For $\mathrm{H}_{2} \mathrm{O}$ we use $1.8 \times 10^{-8}$ $\mathrm{ppmv} / \mathrm{s}$ and 0 for the production and loss respectively. The production term due to $\mathrm{CH}_{4}$ oxidation is estimated from the vertical gradient of $\mathrm{H}_{2} \mathrm{O}$.

Convective injection of water, $\left[\mathrm{H}_{2} \mathrm{O}\right]_{v}^{\text {conv }}$ in Eq. (2) is $100 \%$ RHi calculated for the convective temperature, $\mathrm{T}^{\mathrm{conv}}$. Ice detrained from convection, $\left[\mathrm{H}_{2} \mathrm{O}\right]_{i}^{\text {conv }}$, depends on the convective mechanism being considered. The definitions of $\mathrm{T}^{\text {conv }}$ and $\left[\mathrm{H}_{2} \mathrm{O}\right]_{i}^{\text {conv }}$ are discussed later.

\subsection{CO modeling}

Carbon monoxide is useful for testing the convective parametrization in the model (Folkins et al., 2006a). As has been noted before, when $\left[\mathrm{H}_{2} \mathrm{O}\right]_{v} \geq 100 \% \mathrm{RHi}$, temperature control dominates convective mixing making it difficult to observe any evidence of convective influence on $\mathrm{H}_{2} \mathrm{O}$. This is readily seen in Eq. (2). The condensation rate in supersaturated air is much faster $(1 \mathrm{~h})$ than the convective mixing rate ( $\geq 20$ days) in the TTL. The insoluble tropospheric tracer CO on the other hand, is especially valuable for detecting convective activity in the TTL. In the TTL model, the rate of change of $\mathrm{CO}$ with time can be represented by an equation similar to that given for the time tendency of water vapor, except that all terms involving condensed phases are removed. The 4th term representing convection stands out. Carbon monoxide is destroyed by $\mathrm{OH}$ in the lower stratosphere, producing a vertical gradient. The production and loss rates for $\mathrm{CO}$ use the profiles in Folkins et al. (2006a). As shown in Randel et al. (2006), Schoeberl et al. (2007), and Folkins et al. (2006b), an annual cycle in $\mathrm{CO}$ is produced above the tropopause as a consequence of modulating the vertical gradient in $\mathrm{CO}$ by the annual oscillation in the vertical upwelling. Therefore $\mathrm{CO}$ is a good diagnostic of both convection and the large scale upwelling.

Convective mixing of boundary air $\mathrm{CO}$ is the parameter $[\mathrm{CO}]^{\text {conv }}$ in Eq. (2). We use 1.25 times the v2.2 Aura MLS $147 \mathrm{hPa}$ tropical daily zonal mean CO measurement for $[\mathrm{CO}]^{\text {conv }}$. Scaling the measurement by 1.25 allows the modeled $147 \mathrm{hPa} \mathrm{CO}$ to match the observed CO after smoothing the model field by the Aura MLS averaging kernel.

\section{3 $\mathrm{HDO}$ and $\mathrm{H}_{2}^{18} \mathrm{O}$ modeling}

The heavy water isotopologues condense more efficiently than $\mathrm{H}_{2} \mathrm{O}$ as temperature is lowered. As a result, $\delta \mathrm{D}$ becomes progressively smaller than its surface ratio as rising air is freeze-dried. Therefore $\delta \mathrm{D}$ provides insight into the temperature of the air parcel's most recent condensation event or if convection is mixing deuterium ( ${ }^{18}{ }^{18} \mathrm{O}$ ) enriched ice.

The TTL model partitions HDO and $\mathrm{H}_{2}^{18} \mathrm{O}$ phases according to Eq. (2). The Rayleigh fractionation is applied to the $[X]_{v}^{\text {conv }}$ and $[X]_{s}$ quantities. When the model decides that a cloud is formed, the frost point temperature of $\left[\mathrm{H}_{2} \mathrm{O}\right]_{v}$ is calculated prior to evaluating Eq. (2). Next $[\mathrm{HDO}]_{s}$ is computed from $[\mathrm{HDO}]_{v}$ by integrating the Rayleigh fractionation function from the frost point temperature to the environmental temperature. If $\left[\mathrm{H}_{2} \mathrm{O}\right]_{v} /\left[\mathrm{H}_{2} \mathrm{O}\right]_{s}>1$ after applying Eq. (2), there will be a kinetic isotope effect which inhibits preferential condensation of HDO. The same procedure is applied to $\mathrm{H}_{2}^{18} \mathrm{O}$. The fractionation factors and theory are from Johnson et al. (2001a) and include the kinetic isotope effect (Jouzel and Merlivat, 1984) with updated diffusivity ratios (Cappa et al., 2003). Production of $\mathrm{HDO}$ and $\mathrm{H}_{2}^{18} \mathrm{O}$ from $\mathrm{CH}_{3} \mathrm{D}$ and $\mathrm{CH}_{4}$ oxidation is that for $\mathrm{H}_{2} \mathrm{O}$ scaled by $\delta \mathrm{D}=-70 \%$ and 
$\delta^{18} \mathrm{O}=-23 \%$, respectively (Schmidt et al., 2005). We assume no chemical loss.

The detrainment of $\mathrm{H}_{2} \mathrm{O}$ isotopologues by convection follows Keith (2000) where we assume deep convection lofts air from the cloud base into the TTL without significant mixing. Accordingly, convectively supplied [HDO ${ }_{v}^{\text {conv }}$ and $\left[\mathrm{H}_{2}^{18} \mathrm{O}\right]_{v}^{\text {conv }}$ follow Rayleigh fractionation using the convective temperature profile, ice detrained from convection carries enriched $\mathrm{D}$ and ${ }^{18} \mathrm{O}$ such that $\delta \mathrm{D}$ and $\delta^{18} \mathrm{O}$ in total water are $-550 \%$ and $-80 \%$ respectively. The isotopic ratios for the total $\mathrm{H}_{2} \mathrm{O}$ isotopologues are tunable parameters in this model and we choose values that represent Rayleigh fractionation of vapor up to the level of neutral buoyancy for tropical convection.

\subsection{Convection}

The TTL model is used to investigate three convective transport scenarios summarized in Table 1. The first scenario "slow ascent" limits convection's influence to providing only large scale upwelling without any direct mixing, $\left(1 / \tau_{d}=0\right.$ in Eq. 2). The TTL model has a uniform vertical velocity of $0.23 \mathrm{~mm} / \mathrm{s}$ (with a seasonal amplitude of $0.8 \mathrm{~mm} / \mathrm{s}$ ) throughout the TTL without a LZH and convective mixing. This is similar to the original HG01 model and emulates the convective mechanism in trajectory based models (Gettelman et al., 2002; Jensen and Pfister, 2004; Fueglistaler et al., 2005) where the large scale vertical motion allows some trajectories to cross the clear sky LZH.

The overshooting convective mixing schemes explore the sensitivity of $\mathrm{H}_{2} \mathrm{O}$, $\mathrm{HDO}$, and $\mathrm{H}_{2}^{18} \mathrm{O}$, to different mechanisms for control of $\left[\mathrm{H}_{2} \mathrm{O}\right]_{v}^{\text {conv }}$ and $\left[\mathrm{H}_{2} \mathrm{O}\right]_{i}^{\text {conv }}$, summarized in Table 1 . Overshooting means convection penetrates above the clear sky LZH. Convective mixing occurs at a rate given in Fig. $2\left(\tau_{d}\right.$ in Eq. 2$)$ and includes a LZH. $\left[\mathrm{H}_{2} \mathrm{O}\right]_{i}^{\text {conv }}$ is a free parameter in this model that is not well constrained by observations. We study two convective mechanisms for detraining $\mathrm{H}_{2} \mathrm{O}$ and ice.

The first convective mechanism called "hydrating overshooting convection" assumes convection detrains $100 \%$ RHi computed for its convective temperature. The convective temperature for hydrating overshooting convection is the environmental temperature below the CPT, and above the CPT is the mean of the environmental temperature and the moist adiabatic temperature extrapolated upward from the CPT (Pfister and Jensen, 2007). The convective temperature for hydrating overshooting convection is called the modified environmental temperature, $\mathrm{T}^{\prime}$. Figure 3 shows an example of $\mathrm{T}^{\prime}$. The modified environmental temperature continues to cool above the CPT because the moist adiabat cools more rapidly than the environmental temperature warms, consistent with outgoing longwave radiation (OLR) measurements that are sometimes less than the CPT temperature. Nominally, we assume that hydrating overshooting convection de-
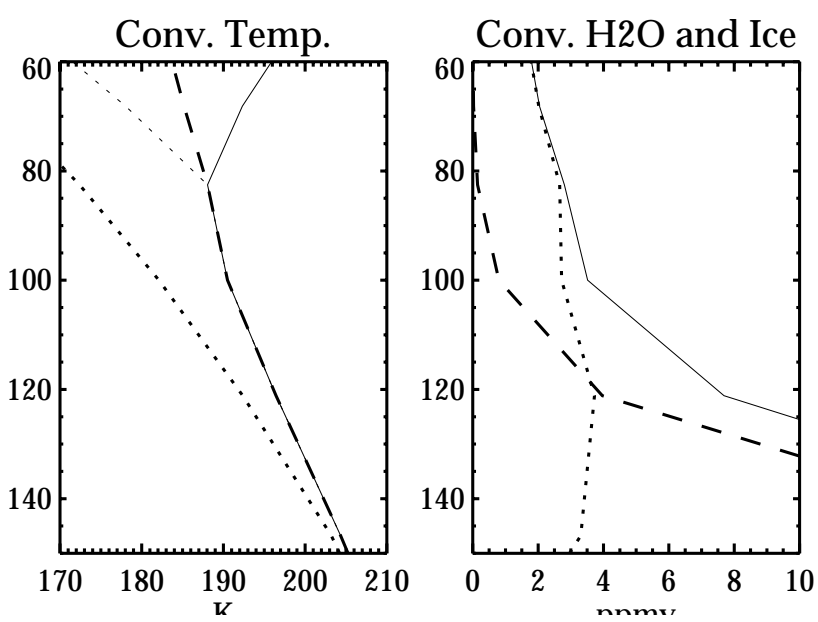

Fig. 3. An illustration of the modified environmental temperature and convectively injected water and ice. The left panel shows the modified environmental temperature (thick dashed) which is an average of the environmental temperature (thin solid) and the moist adiabatic temperature (thin dotted) above the CPT. Below the CPT, the modified environmental temperature is the environmental temperature. The thick dotted is the moist adiabatic temperature above the level of neutral buoyancy. The right panel shows total $\mathrm{H}_{2} \mathrm{O}$ injected by both convective mechanisms. For the hydrating overshooting convection case total $\mathrm{H}_{2} \mathrm{O}$ is injected as vapor. For the adiabatic overshooting convection case, total $\mathrm{H}_{2} \mathrm{O}$ is partitioned into vapor (thick dashed) and ice (thick dotted).

trains no ice but we also consider its sensitivity to this assumption.

The second mechanism called "adiabatic overshooting convection" revisits the Sherwood and Dessler (2001, hereafter referred as SD01) convective dehydration model where $100 \%$ RHi air at the convective temperature, $\mathrm{T}^{\text {conv }}$, following the moist adiabat from the level of neutral buoyancy (set at $160 \mathrm{hPa}$ ) is mixed into the environmental air. As shown in Fig. 3, convection mixes in very dry air because the moist adiabatic temperature is much colder than the environmental temperature. Cloud resolving models lend support to the likelihood that temperature inside overshooting convective turrets is much colder than the environment (Grosvenor et al., 2007; Smith et al., 2006; Jensen et al., 2007). The adiabatic overshooting convection scheme implemented here differs from SD01 by detraining enough ice to inhibit irreversible dehydration. Convective dehydration is not supported by observations or cloud resolving model calculations that show enough ice evaporates after convection collapses to prevent significant dehydration. For a consistent comparison to the hydrating overshooting convection scheme $\left(\left[\mathrm{H}_{2} \mathrm{O}\right]_{i}^{\text {conv }}=0\right)$ we mix enough ice such that the total $\mathrm{H}_{2} \mathrm{O}$ is the same as that in the hydrating overshooting convection test. This is equivalent to increasing the ice retention parameter from 4 to 10 in the SD01 model at the CPT. The adiabatic over- 
Table 1. TTL Model Test Runs.

\begin{tabular}{lcccc}
\hline Convection Scheme & $1 / \tau_{d}$ & $\mathrm{~T}^{\text {conv }}$ & {$\left[\mathrm{H}_{2} \mathrm{O}\right]_{v}^{\text {conv }}$} & {$\left[\mathrm{H}_{2} \mathrm{O}\right]_{i}^{\text {conv }}$} \\
\hline Slow Ascent & 0.0 & $\mathrm{NA}$ & $\mathrm{NA}$ & $\mathrm{NA}$ \\
Hydrating overshooting convection & Fig. 2 & $\mathrm{~T}^{\prime \mathrm{a}}$ & {$\left[\mathrm{H}_{2} \mathrm{O}\right]_{s}\left(\mathrm{~T}^{\prime}\right)$} & 0.0 \\
Adiabatic overshooting convection & Fig. 2 & $\mathrm{~T}_{\operatorname{lnb}}(p / p \operatorname{lnb})^{2 / 7}$ & {$\left[\mathrm{H}_{2} \mathrm{O}\right]_{s}\left(\mathrm{~T}^{\text {conv }}\right)$} & {$\left[\mathrm{H}_{2} \mathrm{O}\right]_{s}\left(\mathrm{~T}^{\prime}\right)-\left[\mathrm{H}_{2} \mathrm{O}\right]_{s}\left(\mathrm{~T}^{\mathrm{conv}}\right)$} \\
\hline
\end{tabular}

a $\mathrm{T}^{\prime}$ is the environmental temperature except above the CPT where a modified scheme described in the text is used.

shooting convection mechanism therefore injects a few parts per million volume (ppmv) of $\mathrm{H}_{2} \mathrm{O}$ in ice which we argue is reasonable. Although observations and numerical simulations using cloud resolving models show ice concentrations of $\sim 1000$ ppmv in the TTL (Webster and Heymsfield, 2003; Jensen et al., 2007), the majority of this ice is unlikely to mix in the TTL because it will sediment too quickly. According to the mircophysical model embedded in a cloud resolving model the concentration of ice in small slowly falling particles $(r<20 \mu \mathrm{m})$ is $\left[\mathrm{H}_{2} \mathrm{O}\right]_{i}^{\text {conv }}<6$ ppmv (Jensen et al., 2007). We also consider this scheme's sensitivity to $\left[\mathrm{H}_{2} \mathrm{O}\right]_{i}^{\text {conv }}$.

\section{Data}

\subsection{Aura MLS measurements}

Aura MLS measures millimeter-sub millimeter wavelength thermal emission from the Earth's atmospheric limb (Waters et al., 2006). The Aura MLS fields of view point in the direction of orbital motion and vertically scan the limb in the orbit plane. Aura MLS produces almost 3500 atmospheric profiles over 14 orbits between $82^{\circ} \mathrm{S}$ to $82^{\circ} \mathrm{N}$ each day.

This study compares the model output to Aura MLS v2.2 $\mathrm{H}_{2} \mathrm{O}$ and CO. As was noted earlier, the TTL model is driven by Aura MLS v2.2 tropical temperature. The precision (after removing an altitude dependent bias) and vertical resolution of the v2.2 temperature measurement are $1-2 \mathrm{~K}$ and $5 \mathrm{~km}$ (Livesey, 2007; Schwartz et al., 2008). Extratropical averages of Aura MLS v2.2 $\mathrm{H}_{2} \mathrm{O}$ and $\mathrm{CO}$ are used for the extratropical concentrations. The tropical average of $147 \mathrm{hPa}$ Aura MLS v2.2 $\mathrm{H}_{2} \mathrm{O}$ and $\mathrm{CO}$ are input into the bottom of the model, and the tropical $147 \mathrm{hPa}$ Aura MLS v2.2 CO multiplied by 1.25 is the $\mathrm{CO}$ convective input. The accuracy for v2. $2 \mathrm{H}_{2} \mathrm{O}$ is $7-12 \%$, with a $3-3.5 \mathrm{~km}$ vertical resolution and a single profile precision of $15 \%$ (Read et al., 2007). The accuracy, vertical resolution and single profile precision for v2.2 $\mathrm{CO}$ is $30 \% \pm 20$ parts per billion volume (ppbv), $4 \mathrm{~km}$, and 20 ppbv (Livesey et al., 2008). All Aura MLS data sets were appropriately screened according to rules given in Livesey (2007).

\subsection{ACE-FTS}

The HDO measurements are provided by ACE-FTS on the Canadian SCISAT-1 mission (Bernath et al., 2005). ACEFTS is a high resolution $\left(0.02 \mathrm{~cm}^{-1}\right)$ infrared Fourier transform spectrometer that measures solar occultation spectra between 2.2 and $13.3 \mu \mathrm{m}\left(750-4400 \mathrm{~cm}^{-1}\right)$. Vertical profiles are retrieved for up to 15 sunrises and 15 sunsets per day whose latitudes vary over an annual cycle from $85^{\circ} \mathrm{S}$ to $85^{\circ} \mathrm{N}$ with an emphasis on the polar regions during winter and spring. The current processing version for the ACE-FTS is version 2.2 (Boone et al., 2005). We use here an official update to the processing called "version 2.2 HDO update" (Nassar et al., 2007), which corrects errors in HDO results found in the original version 2.2 dataset. The ACE-FTS HDO retrievals employ 18 microwindows (spectral intervals of width $0.3-0.5 \mathrm{~cm}^{-1}$ ) in the wavenumber range $1400-1500 \mathrm{~cm}^{-1}$ and 6 microwindows in the range $2610-2675 \mathrm{~cm}^{-1}$.

The altitude range for the HDO retrievals extends from 5 to $38 \mathrm{~km}$. Data for the other isotopologues are not yet released. The vertical resolution and precision of the ACE-FTS HDO are $3-4 \mathrm{~km}$ and $20-40 \%$. The ACE-FTS HDO is not yet validated but the profile average in this paper agrees well with earlier tropical HDO measurements from Atmospheric Trace MOlecule Spectroscopy (ATMOS, Kuang et al., 2003; Gunson et al., 1996) and Aircraft Laser Infrared Absorption Spectrometer (ALIAS, Webster and Heymsfield, 2003). The isotopologue comparisons concentrate on the 2005-2007 time frame where ACE-FTS and Aura MLS v2.2 measurements overlap. Applying the recommended quality screening to the ACE-FTS data produces 260 profiles between $12^{\circ} \mathrm{S}$ and $12^{\circ} \mathrm{N}$.

\section{Results}

\section{1 $\mathrm{H}_{2} \mathrm{O}$}

Figure 4 compares $\mathrm{H}_{2} \mathrm{O}$ time series for the 3 TTL model runs (slow ascent, hydrating overshooting convection, and adiabatic overshooting convection) to v2.2 Aura MLS at $147,121,100,83$, and $68 \mathrm{hPa}$. The Aura MLS $\mathrm{H}_{2} \mathrm{O}$ measurements are daily zonal means between $12^{\circ} \mathrm{S}-12^{\circ} \mathrm{N}$. The model runs have been convolved with the Aura MLS averaging kernel (Rodgers, 1990) and the forward model smoothing 

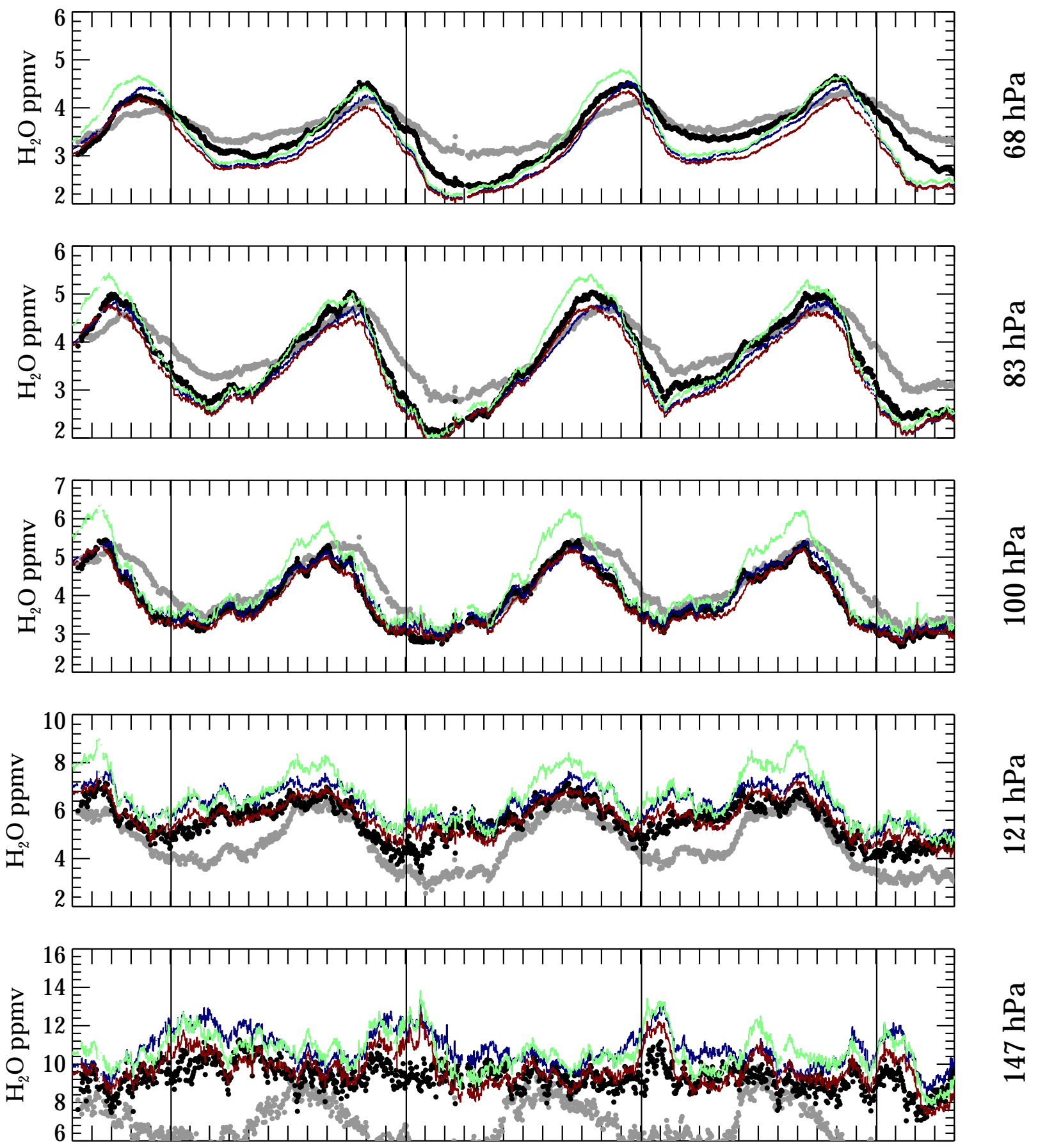

ASOND J FMAM J J A SOND J FMAM J J ASOND J FMAM J J ASOND J FMAM

$20042005 \quad 2006 \quad 2007 \quad 2008$

Fig. 4. $\mathrm{H}_{2} \mathrm{O}$ time series at $147,121,100,83$, and $68 \mathrm{hPa}$, for Aura MLS v2.2 (black points), TTL model runs, slow ascent (blue), hydrating overshooting convection (green), and adiabatic overshooting convection (red). The Aura MLS measurements are daily zonal means between $12^{\circ} \mathrm{S}-12^{\circ} \mathrm{N}$. The model runs are smoothed by the Aura MLS forward model smoothing function and v2.2 averaging kernel (Read et al., 2007). The gray points are the Aura MLS measured extratropical $\mathrm{H}_{2} \mathrm{O}$ used in the TTL model. 
function (Read et al., 2007, 2006). The observations clearly show that the maximum amplitude in the $\mathrm{H}_{2} \mathrm{O}$ annual oscillation occurs at $83 \mathrm{hPa}$. The phase of the annual oscillation shifts with altitude reflecting the transit time of air from the CPT where the annual oscillation is imprinted. This feature is often referred to as a tape recorder (Mote et al., 1996). There is little to no annual oscillation at 147 and $121 \mathrm{hPa}$ in the Aura MLS $\mathrm{H}_{2} \mathrm{O}$. This closely follows the tropical temperature data that shows an annual oscillation $<1 \mathrm{~K}$ at $14 \mathrm{~km}$ becoming $6 \mathrm{~K}$ at the CPT (Randel et al., 2002).

Despite the different transport and convective mixing parameterizations, the model runs show mostly good agreement with each other and the Aura MLS measurements. This result emphasizes the control of regions having the lowest CPT temperature-common to all parameterizations-has in regulating the entry of $\mathrm{H}_{2} \mathrm{O}$ into the stratosphere. This is expected because condensation is the fastest of all processes in Eq. (2). All that matters is that $\mathrm{H}_{2} \mathrm{O}$ transported into the coldest locations is greater than $100 \% \mathrm{RHi}$ (or $160 \% \mathrm{RHi}$ to initiate condensation). The slow ascent run vertically advects $\sim 10 \mathrm{ppmv}$ $\mathrm{H}_{2} \mathrm{O}$ from $14 \mathrm{~km}$ which is greater than the saturation mixing ratio (SMR) of the coldest location. Hydrating overshooting convection directly injects $100 \%$ RHi air throughout the TTL (at a rate decreasing with altitude). Moisture injected above the LZH that is vertically and horizontally advected through the coldest locations is greater than its SMR. Adiabatic overshooting convection introduces two competing processes, one that injects air $\ll 100 \%$ RHi (relative to the environmental air temperature) and another that injects ice some of which can reevaporate.

An interesting feature in Fig. 4 are the brief increases in $147 \mathrm{hPa} \mathrm{H}_{2} \mathrm{O}$ produced by all the model runs during January and February of each year. These increases are due to evaporation of sedimented ice formed in situ near the CPT. There appears to be some evidence of these features in the Aura MLS $147 \mathrm{hPa} \mathrm{H}_{2} \mathrm{O}$ in 2007 and 2008.

The largest difference among the convective transport schemes occurs during the Boreal summertime at the CPT. The slow ascent and adiabatic overshooting convection representations are similar. Hydrating overshooting convection has a wetter warm phase. The difference is caused by hydrating overshooting convection's ability to rapidly inject $100 \%$ RHi vapor in all horizontal grid boxes (not just the coldest regions) in the model with some injection occurring above the CPT. Some $\mathrm{H}_{2} \mathrm{O}$ injected above the CPT in warm grid boxes can by pass the CPT temperature in the coldest locations leading to a slight moistening. This effect appears to be more significant during the Boreal summer because its CPT is lower in altitude. The slow ascent scheme slowly processes all parcels through the coldest regions in the TTL model. Extratropical mixing also acts as a mild dehydrating effect below the CPT and a mild moistening influence above, but sensitivity tests ranging from no extratropical mixing to doubling the rate used here amounts to less than $0.5 \mathrm{ppmv}$ change at the CPT and above (mostly a shift in the abso- lute $\mathrm{H}_{2} \mathrm{O}$ ). The adiabatic overshooting convection scheme involves two competing effects that nearly cancel in comparison to a slow ascent representation. One effect is to detrain and mix dry air which lowers the relative humidity along with ice that evaporates when exposed to warm environmental air.

Within the framework of the TTL model, the $\mathrm{H}_{2} \mathrm{O}$ annual oscillation is sensitive to $\left[\mathrm{H}_{2} \mathrm{O}\right]_{i}^{\text {conv }}$ detrained by convection shown in Fig. 5. It is clear that without ice injection, adiabatic overshooting convection is a powerful dehydrating mechanism that would produce too dry a stratosphere and too weak an annual cycle as noted in earlier work (Sherwood and Dessler, 2001, 2003). To overcome this problem Sherwood and Dessler (2003) included a temporally dependent ice retention factor which itself was dependent on the $100 \mathrm{hPa}$ temperature, hence introducing a tropopause temperature control mechanism into their overshooting convection model. Likewise hydrating overshooting convection detraining ice and adiabatic overshooting convection detraining double the amount of ice than our standard case produce overly large annual cycles in $\mathrm{H}_{2} \mathrm{O}$ and are too moist for pressures greater than $100 \mathrm{hPa}$. Therefore it appears that convection relative to a slow ascent view in a zonal mean sense is nearly neutral or slightly moistening - enough to overcome the mild dehydrating effect of extratropical mixing.

An important question especially in the context of $\mathrm{H}_{2} \mathrm{O}$ trends is whether the tropical stratospheric entry $\mathrm{H}_{2} \mathrm{O}$ is under regional minimum CPT temperature control throughout the year. Of concern is the oft-cited issue of Eularian grid box temperature averages in place of averages of minimum temperature encountered along trajectories (e.g., Fueglistaler et al., 2004). The daily minimum CPT temperature field (defined as the horizontal and vertical grid box having the daily minimum temperature) in the TTL model has a $\sim 8 \mathrm{~K}$ annual oscillation. The Lagrangian cold point based on trajectory analysis using European Center for Medium Range Weather Forecasts 40-year Reanalysis (ERA-40) temperature fields from 1992-2001 has a smaller $4.3 \mathrm{~K}$ annual oscillation (Fueglistaler et al., 2004). Despite the larger CPT oscillation used in the TTL model, it accurately reproduces the observed $\mathrm{H}_{2} \mathrm{O}$ annual cycle because the minimum CPT temperature from the MLS measurements occurs at $83 \mathrm{hPa}$ during the cold phase and $100 \mathrm{hPa}$ during the warm phase. This change in altitude reduces the $\mathrm{H}_{2} \mathrm{O}$ annual oscillation by 0.4 ppmv than would be achieved if the minimum CPT temperature always occurred at $100 \mathrm{hPa}$ (as assumed in Read et al., 2008).

There is additional evidence that there is enough moisture to sustain ice formation all year. Subvisible cirrus near the CPT is present all year (Wang et al., 1996). Fluctuations in the Aura MLS grid box minimum temperature field during the Boreal summers (Fig. 1) qualitatively follow those in the Aura MLS $\mathrm{H}_{2} \mathrm{O}$ lending evidence that the Boreal summer is under minimum CPT temperature control. The fluctuations which have a periodicity of 1-2 months when present are probably CPT temperature anomalies associated with the 


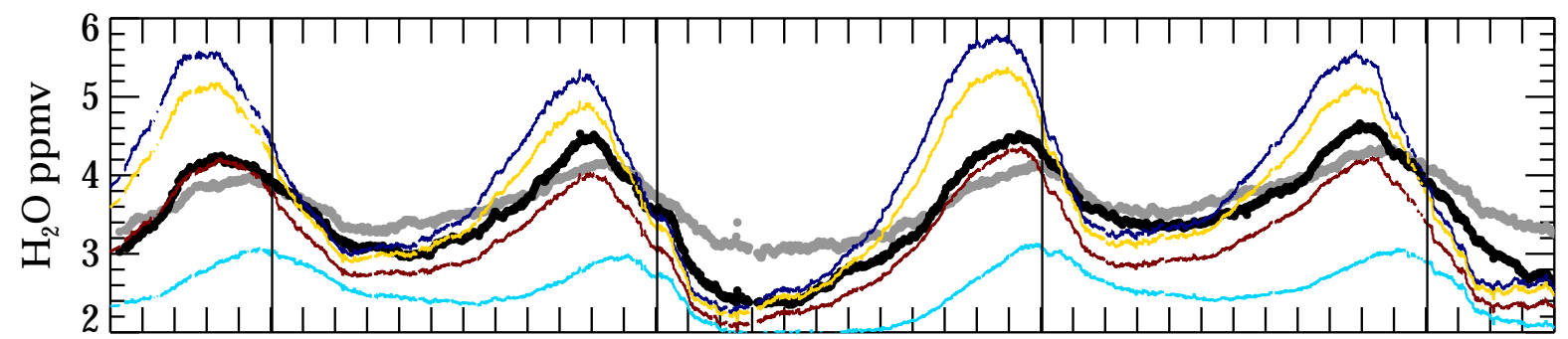

동

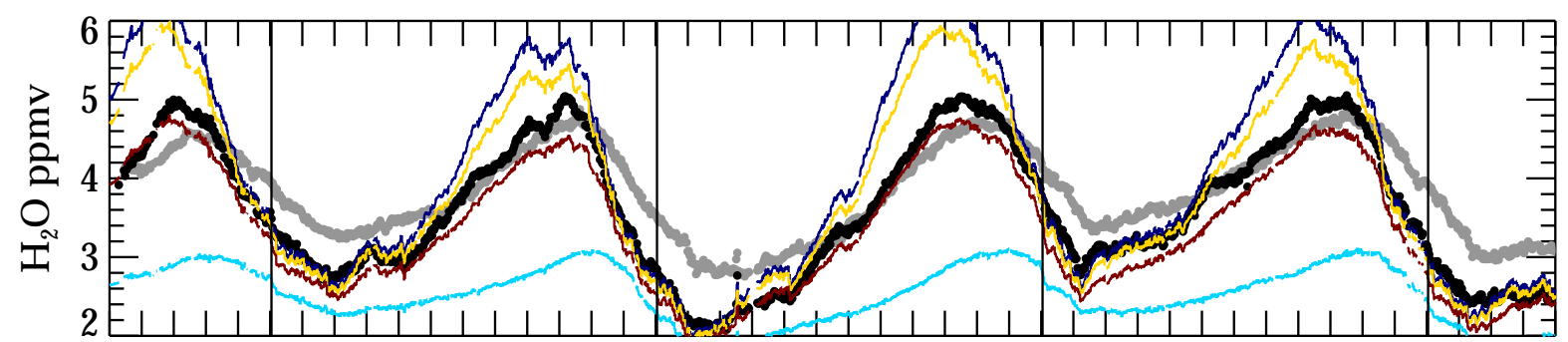

$\frac{\sigma}{\infty}$

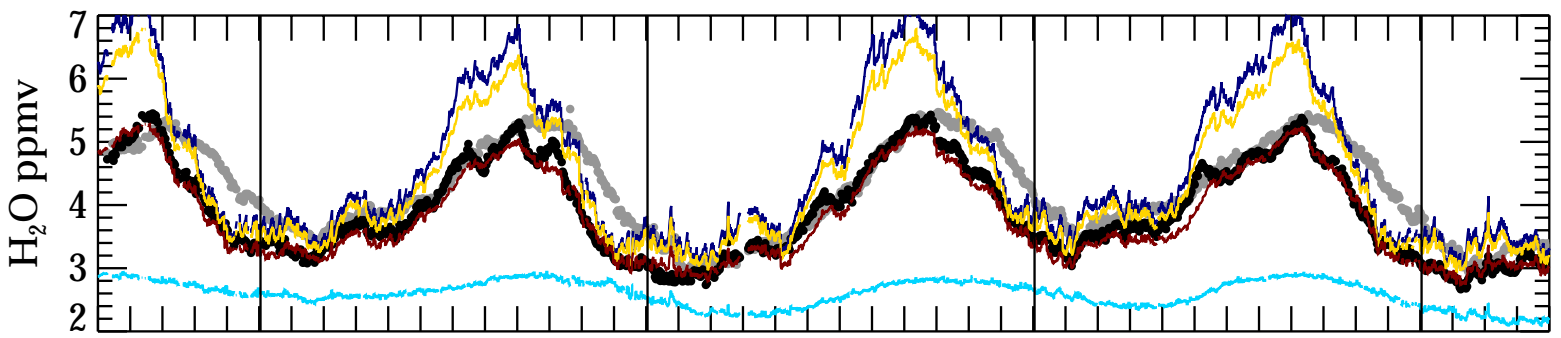

동

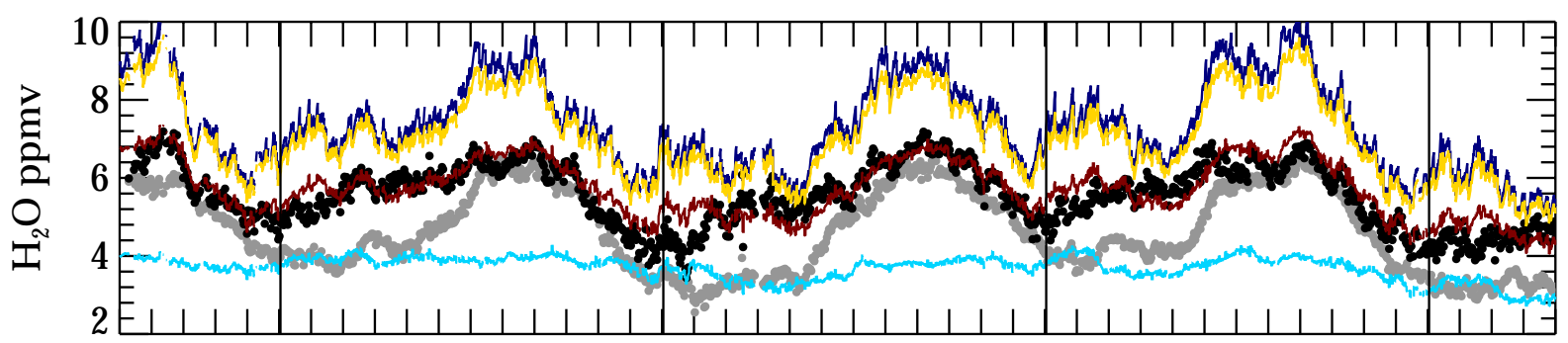

도

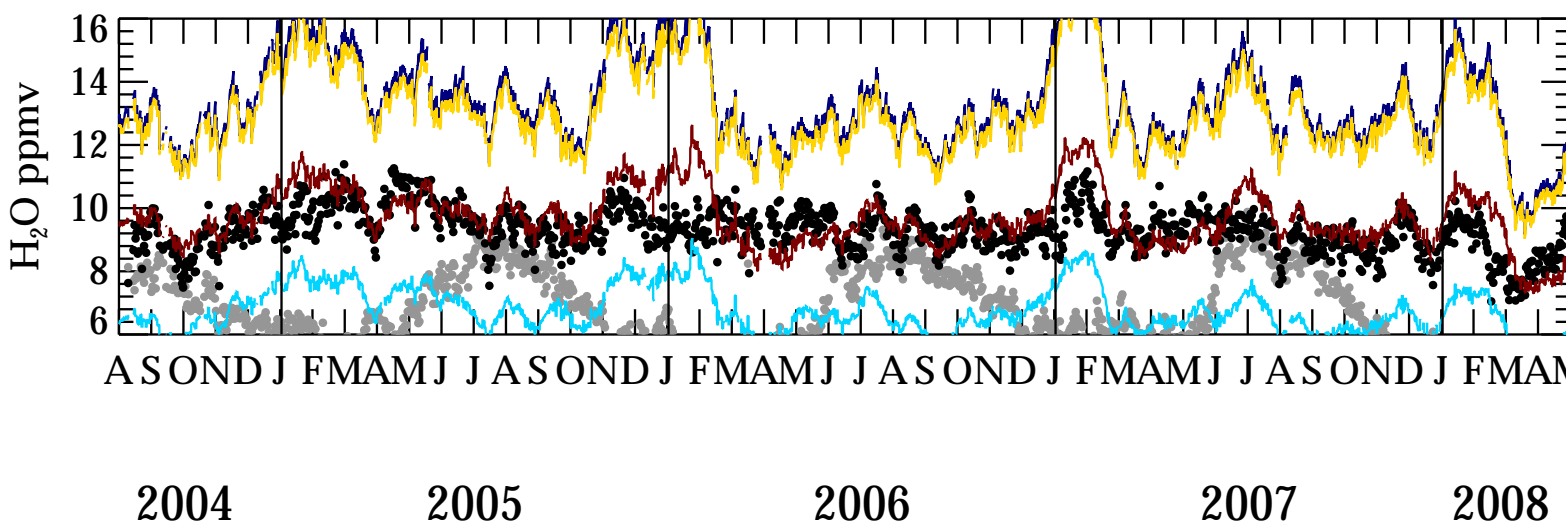

Fig. 5. Same as Fig. 4 except it shows comparisons of model sensitivity tests to the hydrating overshooting convection scheme with equal amounts of $\mathrm{H}_{2} \mathrm{O}$ and ice injected (dark blue), adiabatic overshooting convection schemes with no ice (light blue), twice as much ice shown in Fig. 3 (yellow), and the nominal run (dark red). 
Madden Julian Oscillation (Madden and Julian, 1994; Wong and Dessler, 2007).

\section{$4.2 \mathrm{CO}$}

Figure 6 compares $\mathrm{CO}$ time series for four model runs to v2.2 Aura MLS measurements at 147, 100, and $68 \mathrm{hPa}$. The Aura MLS CO measurements are daily zonal means between $12^{\circ} \mathrm{S}-12^{\circ} \mathrm{N}$. The model runs have been convolved with the Aura MLS averaging kernel (Rodgers, 1990) and the forward model smoothing function (Read et al., 2007, 2006). The TTL model runs show slow ascent with and without extratropical mixing and adiabatic overshooting convection with and without extratropical mixing. The $\mathrm{CO}$ fields produced by the direct convective injection runs are insensitive to $\left[\mathrm{H}_{2} \mathrm{O}\right]_{i}^{\text {conv }}$ and $\mathrm{T}^{\mathrm{conv}}$. Aura MLS observations of $\mathrm{CO}$ show a semiannual oscillation in the upper troposphere $(147 \mathrm{hPa})$ propagating up to the CPT and an annual oscillation at the top of the TTL. These features are generally understood to be the combined effects of convective mixing of boundary layer air polluted with $\mathrm{CO}$ from biomass burning and the annual oscillation of the tropical upwelling acting on the vertical gradient of CO (Schoeberl et al., 2006; Randel et al., 2007; Folkins et al., 2006b; Schoeberl et al., 2007).

The slow ascent runs show poor agreement with Aura MLS for the annual behavior of CO. The run neglecting extratropical mixing fails to produce a semiannual oscillation at $100 \mathrm{hPa}$. The chemical destruction of CO modulated by the annual oscillation in the upwelling velocity dominates and removes structure in $\mathrm{CO}$ introduced in the lower boundary of the TTL. Including extratropical mixing preserves some of this structure because it is present in the extratropical CO field - a consequence of monsoonal and southern hemispherical circulations. The amplitude however, is too weak and close examination reveals that the phase is lagged relative to measurements. This results from a phase lag between the tropical and extratropical CO measurements from Aura MLS. The convective runs agree much better, particularly with extratropical mixing included. The dominant effect of adding extratropical mixing is not to mix in extratropical $\mathrm{CO}$ but instead to increase the convective mixing rate and extend it to higher altitudes (remember that the convective mass flux balances upward and extratropical mass fluxes). This is why paradoxically, adding extratropical mixing makes the TTL model appear to depart further from the extratropical CO. The temporal variability of modeled $\mathrm{CO}$ in the convective runs is insensitive to the scaling applied to the Aura MLS $147 \mathrm{hPa} \mathrm{CO}$ used as the convective input; however, scaling by 1.25 produces better quantitative agreement for the annual mean. The Aura MLS CO measurements clearly show that convection is mixing air into the TTL up to the CPT.

The observed CO features are also reproduced with the Goddard Modeling Initiative (GMI) Chemical Transport Model (CTM, Schoeberl et al., 2006). The GMI-CTM is driven by GEOS-4 meteorology. Like our model, the GMI-
CTM underestimates the amplitude of the semiannual oscillation in CO. The semiannual oscillation in $\mathrm{CO}$ from the GMI-CTM doesn't propagate to as high an altitude as in our TTL model or in Aura MLS CO. This feature is consistent with the behaviors of the Zhang and McFarlane (1995, GEOS-4/GMI-CTM) and TCM convection schemes (Folkins et al., 2006a).

\subsection{HDO}

Figure 7 shows a comparison between an ACE-FTS 2-year $(2005 / 2006)$ tropical average $\delta$ D profile and the model runs. The ACE-FTS $\delta$ D profile shows a weak, slightly positive gradient in the TTL. This is broadly consistent with ATMOS (Kuang et al., 2003) $\delta \mathrm{D}$. Quantitatively the values are in excellent agreement $(\sim-650 \%$, same as ATMOS). Also shown are the individual measurement points. Like ATMOS, most of the ACE-FTS $\delta$ D measurements fall within $\sim 50 \%$ o of the mean. Overlaid is the 2 year average $\delta \mathrm{D}$ from $10 \mathrm{TTL}$ model runs exploring sensitivities to the convective scheme, $\left[\mathrm{H}_{2} \mathrm{O}\right]_{i}^{\text {conv }}$ and extratropical mixing.

The slow ascent run without extratropical mixing falls between the two Rayleigh distillation curves that represent the seasonal extremes. This is expected because only temperature controlled freeze-drying occurs. The kinetic isotope effect is negligible in these model runs because $\mathrm{H}_{2} \mathrm{O}$ rapidly relaxes to $100 \%$ RHi upon condensation. It is worth mentioning however, observations show that the base of the TTL is significantly enriched in HDO relative to the 1-D Rayleigh distillation from the surface. This is evidence of reevaporation of HDO enriched ice detrained from tropical deep convection (Keith, 2000). The solid line showing excellent agreement with observations includes extratropical mixing. The good agreement achieved by including extratropical mixing results from a process that relaxes the TTL to extratropical observations and should not be interpreted as support for lack of evidence for direct convective mixing. Stratospheric mixing in the Gettelman and Webster (2005) isotopologue model is treated similarly and may have helped that model achieve good results without direct convective mixing.

The hydrating overshooting convection runs, generally show the poorest agreement with the observations. Without extratropical mixing and without any detrained ice, $\delta \mathrm{D}$ follows Rayleigh distillation from the surface and is much too depleted. This implies that in the tropics convection does not sediment all its ice but some evaporates consistent with the Keith (2000) investigation who arrived at the same conclusion. Even adding an equal amount of detrained ice $\left(\left[\mathrm{H}_{2} \mathrm{O}\right]_{i}^{\text {conv }}=\left[\mathrm{H}_{2} \mathrm{O}\right]_{v}^{\text {conv }}=\left[\mathrm{H}_{2} \mathrm{O}\right]_{s}\left(\mathrm{~T}^{\prime}\right)\right)$ helps but without extratropical mixing, the results are still excessively depleted. Only when extratropical mixing is included along with ice is reasonable agreement achieved. However this configuration produces an annual oscillation in lower stratospheric $\mathrm{H}_{2} \mathrm{O}$ that is much larger than observed. Therefore it appears 

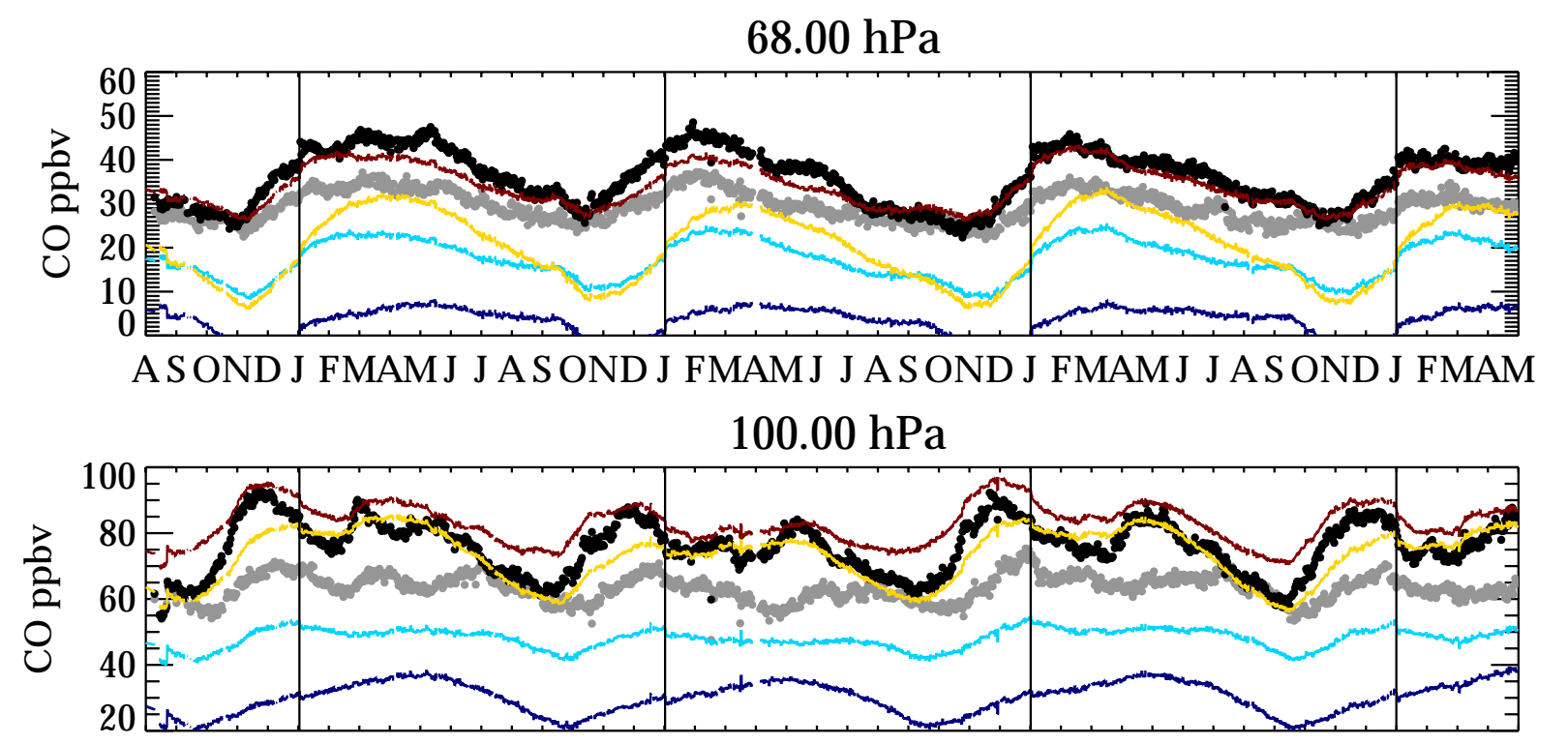

A SOND J FMAMJ J A SOND J FMAM J J ASOND J FMAM J J A SOND J FMAM

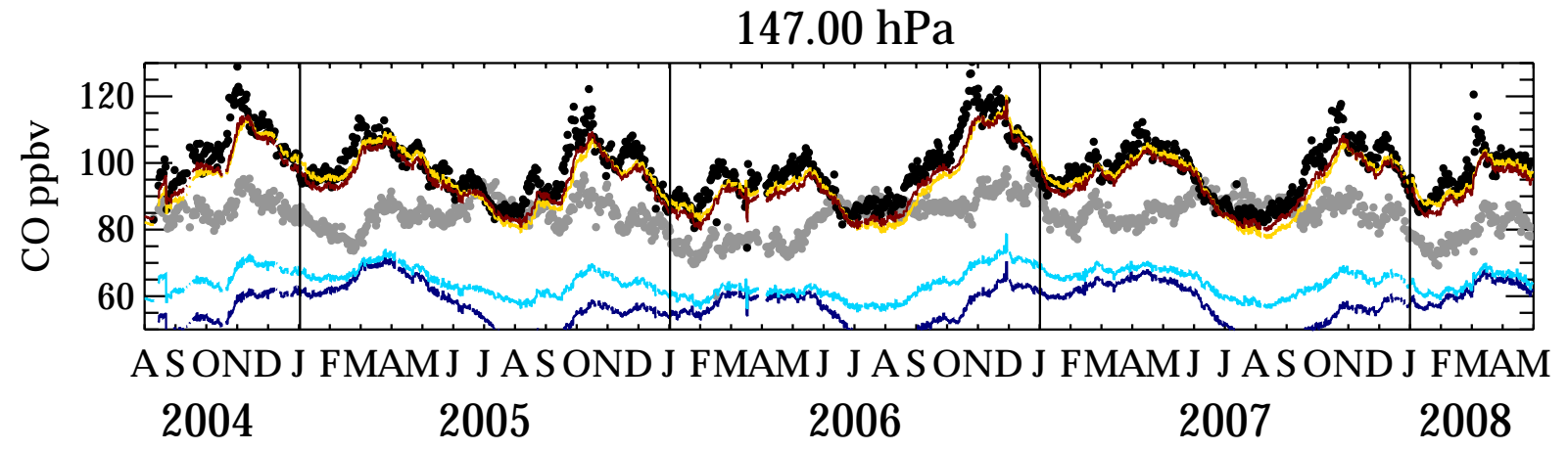

Fig. 6. Same as Fig. 4 but for CO. TTL model runs show slow ascent runs without extratropical mixing (dark blue), with extratropical mixing (light blue), adiabatic overshooting convection without extratropical mixing and adiabatic overshooting convection with extratropical mixing. The model runs have been smoothed by the Aura MLS forward model smoothing function and v2.2 averaging kernel (Read et al., 2007)

difficult to simultaneously achieve good agreement with $\mathrm{H}_{2} \mathrm{O}$ and $\delta \mathrm{D}$ with hydrating overshooting convection.

The adiabatic overshooting convection runs show best agreement with ACE-FTS observations with and without extratropical mixing. Perhaps most importantly, it produces a nearly constant $\delta \mathrm{D}$ ratio in the TTL in the absence of extratropical mixing. This point was strongly emphasized as favorable support for the overshooting convection dehydration model (Dessler and Sherwood, 2003). The effect of extratropical mixing is $\sim 50 \%$ o. The small change between having or not including extratropical mixing eliminates the need to invoke a separate mechanism to explain the extratropical $\delta \mathrm{D}$ ratio. The result in Fig. 7 is nearly insensitive to the amount of ice retained. Doubling the ice retention has almost no effect on $\delta \mathrm{D}$ except to improve agreement with ACE-FTS between $121-147 \mathrm{hPa}$. The insensitivity of $\delta \mathrm{D}$ to the amount of retained ice precludes its quantification. Also note that the adiabatic overshooting convection (and hydrating overshooting convection) model run unlike slow ascent does not depend on the $\delta \mathrm{D}$ prescribed for the lower model boundary because air sinks at this level. However, the convective schemes have a near unit dependence on the $\delta \mathrm{D}$ prescribed for convective ice.

The reason why adiabatic convention is so effective at enriching the air with HDO is its ability to mix and reevaporate HDO enriched ice even in saturated environmental air. A convection scheme detraining $100 \% \mathrm{RHi}$, inhibits ice evaporation and hence the $\delta \mathrm{D}$ remains close to that of the convective vapor. In the adiabatic overshooting convection representation, convection desiccates the air which allows more HDO enriched ice to evaporate. Ice evaporates even if the environmental air is initially saturated. This is the fundamental 


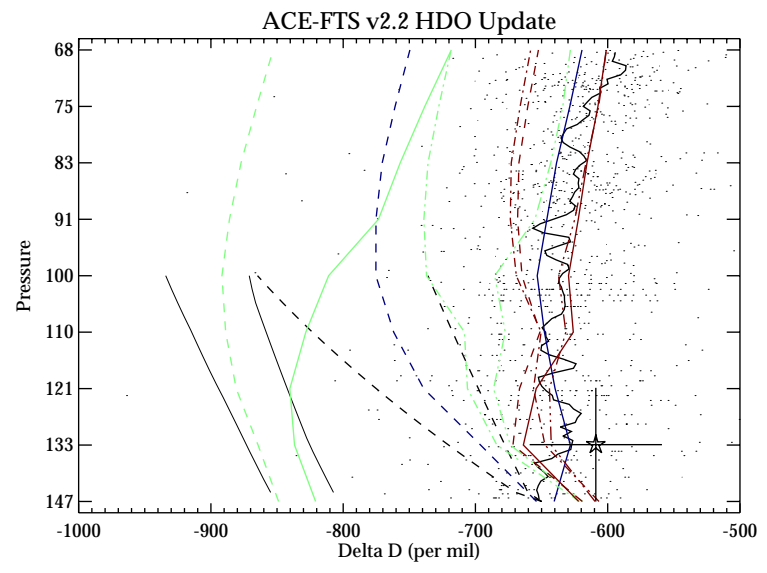

Fig. 7. The black points are ACE FTS measurements of $\delta \mathrm{D}$ between $12^{\circ} \mathrm{S}$ to $12^{\circ} \mathrm{N}$ for 2005 and 2006. The mean of the ACE-FTS $\delta \mathrm{D}$ is overlaid (black line). The TTL model runs for the same time period are: 1) slow ascent (blue) with extratropical mixing (solid) and without extratropical mixing (dashed), 2) hydrating overshooting convection (green) with extratropical mixing no ice detrained (solid), without extratropical mixing and no ice detrained (dashed), with extratropical mixing and an equal amount of ice and vapor detrained (dashed-dot-dot-dot) and without extratropical mixing but with an equal amount of ice and vapor detrained (dashed-dot), and 3) adiabatic overshooting convection (red) with extratropical mixing and nominal ice detrained (Fig. 3, solid), without extratropical mixing and nominal ice detrained (dashed), with extratropical mixing and twice the nominal ice ice detrained (dashed-dot-dot-dot) and without extratropical mixing but with twice nominal ice detrained (dashed-dot). The star is an average of TTL measurements made during CRYSTAL-FACE by ALIAS with the vertical bar representing the altitude coverage of the average and the horizontal bar representing accuracy. The thin solid black lines are Rayleigh distillation curves representing the seasonal extremes in temperature from the surface. The thick dashed black lines are Rayleigh distillation curves representing the seasonal extremes beginning at the prescribed $\delta \mathrm{D}$ for the lower TTL boundary.

difference between the recent Dessler et al. (2007, DHF07 hereinafter) modification to the Fueglistaler et al. (2005) model and the earlier Dessler and Sherwood (2003) model or the adiabatic overshooting convection configuration described here. The DHF07 model uses a mixing scheme based on temporally relaxing the environment to $100 \%$ RHi using HDO enriched vapor. As trajectories encounter saturated regions, convection does nothing. Therefore convection has its greatest impact on low relative humidity air. However, the average relative humidity of the TTL and upper troposphere is generally quite high $\sim 50-75 \%$ RHi making convective enrichment less effective. This is why DHF07 needs to use a much higher $\delta \mathrm{D}$ ratio $(-100 \% 0)$ in convectively detrained vapor to achieve the same effect as $-565 \%$ o did in their earlier model.

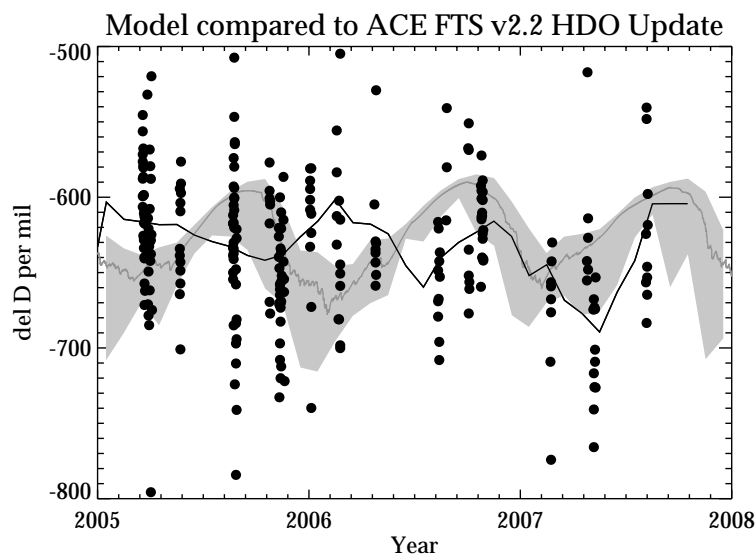

Fig. 8. ACE-FTS $\delta \mathrm{D}$ measurements between $12^{\circ} \mathrm{S}$ and $12^{\circ} \mathrm{N}$ between 100 and $80 \mathrm{hPa}$ (solid circles) shown as a function of time. The black solid line is a temporally smoothed mean of the ACEFTS data. The gray shading represents the longitudinal variation of $\delta \mathrm{D}$ from the adiabatic overshooting convection scheme. Dark gray is the mean of the adiabatic overshooting convection $\delta \mathrm{D}$.

Figure 8 shows a time series of the $\delta \mathrm{D}$ measured by ACEFTS and computed by the adiabatic overshooting convection model run between 100 and $80 \mathrm{hPa}$. We show the time and value of all the ACE-FTS measurements to reveal the seasonality and spread of measurements. A smoothed running mean for the ACE-FTS measurements is overlaid. A 2-D snapshot of the TTL model is saved for each month. The model data plotted represent only 24 discrete times, each separated by 1 month. The longitudinal spread of $\delta \mathrm{D}$ is shown in shaded gray with its running mean overlaid. Because we only save a small sample among many time steps, the variation is certainly underestimated but is sufficient to convey the basic behavior. The model shows a weak annual oscillation that is smaller than the spread of measurements seen in the ACE-FTS observations. Perhaps not surprisingly, the model produces minimum $\delta \mathrm{D}$ during the cold dry phase of the annual oscillation in CPT temperatures. The running mean of the ACE-FTS data also show a weak seasonal dependence but with opposite phasing.

The model also shows an annual oscillation in the spread of $\delta \mathrm{D}$ ratios whose maximum occurs during the cold phase of the CPT temperature annual cycle. The cold phase has a stronger longitudinal gradient in $\delta \mathrm{D}$ because convective supply of HDO enriched ice is re-depleted by in situ Rayleigh distillation whenever irreversible freeze-drying occurs. During the warm phase of the CPT temperature oscillation, Rayleigh distillation by in situ freezing is less prevalent and convective ice detrainment and extratropical mixing both of which have constant $\delta \mathrm{D}$ ratios operate to reduce the longitudinal spread in $\delta \mathrm{D}$. ACE-FTS doesn't show a strong annual oscillation in the spread of HDO throughout the year. This is further evidence that the in situ irreversible freeze-drying is dehydrating air throughout the year. 


\section{$4.4 \quad \mathrm{H}_{2}^{18} \mathrm{O}$}

Figure 9 shows model calculations for $\delta^{18} \mathrm{O}$. Unfortunately there are no global data sets yet available for comparisons. However, we have shown an average of clear sky/TTLscreened measurements from ALIAS during the Cirrus Regional Study of Tropical Anvils and Cirrus Layers-Florida Area Cirrus Experiment campaign (Webster and Heymsfield, 2003; Gettelman and Webster, 2005). The model results are interesting because the relative behavior of $\delta \mathrm{D}$ to $\delta^{18} \mathrm{O}$ is useful to detect persistent supersaturation. Currently, there is much speculation regarding how supersaturated the tropopause is (Jensen et al., 2005). In situ aircraft measurements of $\mathrm{H}_{2} \mathrm{O}$ in the TTL support high persistent supersaturation whereas satellite and balloon frost point hygrometers show less. The difference is $\sim 30 \%$ near the tropopause between Aura MLS and balloon frost point versus a suite of in situ hygrometers flown on the WB57 aircraft (Read et al., 2007).

It is known that the distillation of isotopologues in supersaturated air affects $\delta^{18} \mathrm{O}$ more strongly than $\delta \mathrm{D}$ and therefore $\delta^{18} \mathrm{O}$ relatively speaking will show less depletion and greater departures from Rayleigh fractionation. It has been argued that the weak dependence of observed $\delta^{18} \mathrm{O}$ relative to $\delta \mathrm{D}$ as a function of $\mathrm{H}_{2} \mathrm{O}$ in the uppermost troposphere was evidence of significant supersaturation occurring in thin cirrus clouds (Gettelman and Webster, 2005). This is not a robust conclusion however because our modeling study shows that the adiabatic overshooting convection scheme also produces similar behavior given the limited amount of available data without supersaturation. It is worth noting that published results from models by Gettelman and Webster (2005) and Schmidt et al. (2005) like this TTL model produce less depleted $\delta^{18} \mathrm{O}$ ratios than observed by ALIAS but are within its large uncertainty.

\section{Conclusions}

We have described a conceptual 2-D TTL model that includes horizontal transports through cold traps, extratropical mixing, and convection. The TTL model is used to study how in situ freeze-drying, extratropical mixing and convection affect the concentrations of $\mathrm{H}_{2} \mathrm{O}, \mathrm{HDO}, \mathrm{H}_{2}^{18} \mathrm{O}$, and $\mathrm{CO}$ entering the tropical stratosphere.

We summarize our findings as follows. Based on model comparisons with Aura MLS, $\mathrm{H}_{2} \mathrm{O}$ entering the stratosphere is predominantly determined by the grid box having the lowest CPT temperature throughout the year. This conclusion is consistent with other observations and studies. Temporal wave structure in the longitude bin having the minimum Aura MLS temperature is also present in Aura MLS $\mathrm{H}_{2} \mathrm{O}$. Spatial variability seen in ACE-FTS $\delta \mathrm{D}$ throughout the year also supports year-long CPT temperature control. All year temperature control dominated by the coldest regions is sup-

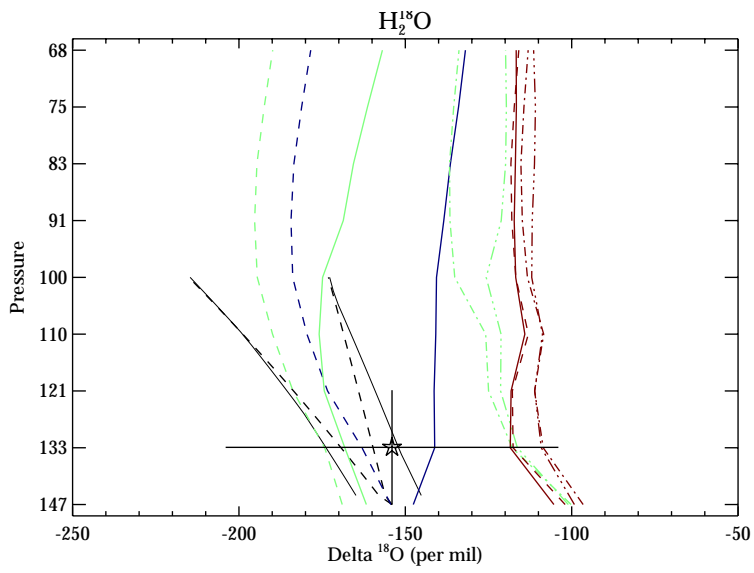

Fig. 9. Same as Fig. 7 but for $\delta^{18} \mathrm{O}$.

ported by more detailed models such as Fueglistaler et al. (2005). Extratropical mixing mildly dehydrates the TTL but not quite enough to cause subsaturation during the Boreal summer. No obvious signature of convection shows in the zonal mean time series of $\mathrm{H}_{2} \mathrm{O}$ suggesting that the zonal mean impact of convection appears to have little effect as has been successfully simulated with our adiabatic overshooting convection scheme. The Aura MLS CO measurement clearly provides evidence for convective mixing in the TTL up to at least the CPT. The heavy water isotopologues support convective mixing of both subsaturated air and ice. Because the $\delta \mathrm{D}$ (or $\delta^{18} \mathrm{O}$ ) profile is very insensitive to the amount of ice retained, they provide no constraint on how much ice is detrained. These three measurements together support the adiabatic overshooting convection scheme which injects subsaturated air and boundary layer trace gases directly into the TTL but dehydration and Rayleigh distillation of the isotopologues are reversed by detraining ice.

These studies may shed some light on the stratospheric $\mathrm{H}_{2} \mathrm{O}$ trend puzzle (Rosenlof et al., 2001). A number of ideas have been advanced which include widening of the tropical upwelling belt (Zhou et al., 2001; Seidel et al., 2007), changes in tropical sea surface temperature and convection (Rosenlof and Reid, 2008), microphysical changes in convection associated with increased aerosol loading from biomass burning (Sherwood, 2002), and increased loading of sulfate aerosols in the TTL which form smaller non sedimenting ice particles that evaporate upon upwelling into the warmer stratosphere (Notholt et al., 2005). Because of successes in modeling stratospheric entry $\mathrm{H}_{2} \mathrm{O}$ during the last $\sim 15$ years with a temperature control model it has also been suggested that the historical data may be suspect as its implied entry $\mathrm{H}_{2} \mathrm{O}$ is too dry to be explained by CPT temperature control (Fueglistaler and Haynes, 2005). We urge some caution in accepting this view because $\mathrm{H}_{2} \mathrm{O}$ entering the stratosphere may not have always been under CPT temperature control. 


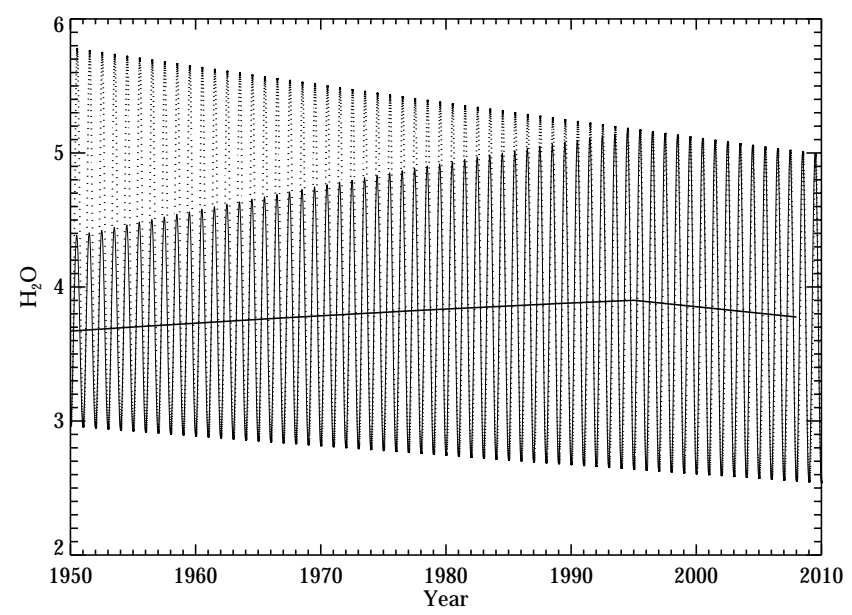

Fig. 10. A schematic representation of how $\mathrm{H}_{2} \mathrm{O}$ can show the observed trend as described in the text. The dots are the SMR under cold trap temperature control assuming $-0.15 \mathrm{~K} /$ decade tropopause temperature trend (Lanzante et al., 2003). The thin line is $\mathrm{H}_{2} \mathrm{O}$ under increasing convective influence assumed here to reduce the time the tropics is subsaturated by $1 \%$ per year. The thick line is a hypothetical entry $\mathrm{H}_{2} \mathrm{O}$ trend.

The decades long increase in stratospheric $\mathrm{H}_{2} \mathrm{O}$ could be evidence of strengthening convective influence putting the TTL under cold trap temperature control throughout the year. Here we assume that currently convection has a mild moistening effect between the LZH and the CPT. A simple scenario has the declining CPT temperature trend associated with increased upwelling (Randel et al., 2006) which in turn leads to increased convective mixing in the TTL (Fig. 2, Folkins et al., 2006a). It is possible that decades ago, weaker upwelling would have weakened convective mixing above the LZH, allowing extratropical mixing to maintain a subsaturated cold trap during a significant portion of the year. The annual average $\mathrm{H}_{2} \mathrm{O}$ entering the stratosphere would be closer to Boreal winter-time values. As upwelling increases, convective moistening in the TTL increases the percentage of the year that the TTL is under cold trap temperature control. This causes an increase in $\mathrm{H}_{2} \mathrm{O}$ because the warmer temperature SMRs fold into the annual average. Once the TTL is under cold trap temperature control all year, the long term trend in the CPT temperature takes effect causing the decline observed in contemporary $\mathrm{H}_{2} \mathrm{O}$ measurements (Randel et al., 2006). Figure 10 shows schematically how this might work. This mechanism could not explain the rapid rise implied by the original processing of the historical data but would be consistent with the less steep rise from recently published corrected data (Scherer et al., 2008). Microphysical processes as suggested by Sherwood (2002), supported by Grosvenor et al. (2007), when coupled to the adiabatic overshooting convection scheme could produce the extreme aridity implied by the uncorrected pre-1980 data by provid- ing an explanation that could cause convection to transition over time from a dehydrating to a hydrating source in the TTL.

Acknowledgements. The authors thank Steven Sherwood, Andy Dessler, Karen Rosenlof, Stefan Fueglistaler, and 4 anonymous referees for helpful comments and suggestions. The research described here done at the Jet Propulsion Laboratory, California Institute of Technology, was under contract with the National Aeronautics and Space Administration. We thank the Canadian Space Agency (CSA) for funding the ACE mission and supplying the HDO data.

Edited by: P. Haynes

\section{References}

Andrews, A. E., Boering, K. A., Daube, B. C., Wofsy, S. C., Hintsa, E. J., Weinstock, E. M., and Bui, T. P.: Empirical Age Spectra for the Lower Tropical Stratosphere from In-Situ Observations of $\mathrm{CO}_{2}$ : Implications for Stratospheric Transport, J. Geophys. Res., 104, 26 581-26 595, 1999.

Bernath, P. F., McElroy, C., Abrams, M., Boone, C., Butler, M., Camy-Peyret, C., Carleer, M., Clerbaux, C., Coheur, P., Colin, R., DeCola, P., DeMazire, M., Drummond, J., Dufour, D., Evans, W., Fast, H., Fussen, D., Gilbert, K., Jennings, D., Llewellyn, E., Lowe, R., Mahieu, E., McConnell, J., McHugh, M., McLeod, S., Michaud, R., Midwinter, C., Nassar, R., Nichitiu, F., Nowlan, C., Rinsland, C., Rochon, Y., Rowlands, N., Semeniuk, K., Simon, P., Skelton, R., Sloan, J., Soucy, M.-A., Strong, K., Tremblay, P., Turnbull, D., Walker, K., Walkty, I., Wardle, D., Wehrle, V., Zander, R., and Zou, J.: Atmospheric Chemistry Experiment (ACE): Mission Overview, Geophys. Res. Lett., 32, L15S01, doi:10.1029/2005GL022386, 2005.

Boehm, M. T., Verlinde, J., and Ackerman, T. P.: On the Maintenance of High Tropical Cirrus, J. Geophys. Res., 104, 24423 24 433, 1999.

Bonazzola, M. and Haynes, P. H.: A trajectory-based study of the tropical tropopause region, J. Geophys. Res., 109, D20112, doi10:1029/2003JD000511, 2004.

Boone, C. D., Nassar, R., Walker, K., Rochon, Y., McLeod, S., Rinsland, C., and Bernath, P.: Retrievals for the Atmospheric Chemistry Experiment Fourier-transform spectrometer, Appl. Optic, 44, 7218-7231, 2005.

Brewer, A. W.: Evidence for a world circulation provided by the measurements of helium and water vapour distribution in the stratosphere, Q. J. R. Meteor. Soc., 75, 351-363, 1949.

Cappa, C. D., Hendricks, M. B., DePaolo, D. J., and Cohen, R. C.: Isotopic Fractionation of Water during Evaporation, J. Geophys. Res., 108, 4525, doi:10.1029/2003JD003597, 2003.

Danielsen, E. F.: A dehydration mechanism for the stratosphere, Geophys. Res. Lett., 9, 605-608, 1982.

Danielsen, E. F.: In situ evidence of rapid, vertical irreversible transport of lower tropospheric air into the lower stratosphere by convective cloud turrets and by large-scale upwelling in tropical cyclones, J. Geophys. Res., 98, 8665-8681, 1993.

Dessler, A. E.: The Effect of Deep, Tropical Convection on the Tropical Tropopause Layer, J. Geophys. Res., 107, 4033, doi:10.1029/2001JD000511, 2002. 
Dessler, A. E. and Sherwood, S. C.: A model of HDO in the tropical tropopause layer, Atmos. Chem. Phys., 3, 4489-4501, 2003, http://www.atmos-chem-phys.net/3/4489/2003/.

Dessler, A. E., Hanisco, T. F., and Füglistaler, S. A.: The Effects of Convective Ice Lofting on $\mathrm{H}_{2} \mathrm{O}$ and HDO in the TTL and Tropical Lower Stratosphere, J. Geophys. Res., 112, D18309, doi:10.1029/2007JD008609, 2007.

Folkins, I. and Martin, R. V.: The Vertical Structure of Tropical Convection and its Impact on the Budgets of Water Vapor and Ozone, J. Atmos. Sci., 62, 1560-1573, 2005.

Folkins, I., Loewenstein, M., Podolske, J., Oltmans, S. J., and Proffit, M.: A Barrier to Vertical Mixing at $14 \mathrm{~km}$ in the Tropics: Evidence from Ozonesondes and Aircraft Measurements, J. Geophys. Res., 104, 22 102-22 102, 1999.

Folkins, I., Bernath, P., Boone, C., Donner, L. J., Lesins, G., Martin, R. V., Sinnhuber, B.-M., and Walker, K.: Testing Convective Parameterizations with Tropical Measurements of $\mathrm{HNO}_{3}, \mathrm{CO}$, $\mathrm{H}_{2} \mathrm{O}, \mathrm{O}_{3}$ : Implications for the Water Vapor Budget, J. Geophys. Res., 111, D23304, doi:10.1029/2006JD007325, 2006a.

Folkins, I., Bernath, P., Boone, C., Lesins, G., Thompson, A. M., Walker, K., and White, J. C.: Seasonal Cycles of $\mathrm{O}_{3}$, CO, and Convective Outflow at the Tropical Tropopause, Geophys. Res. Lett., 33, L16802, doi:10.1029/2006GL026602, 2006 b.

Fueglistaler, S. and Fu, Q.: Impact of Clouds on Radiative Heating Rates in the Tropical Lower Stratosphere, J. Geophys. Res., 111, D23202, doi:10.1029/2006JD007273, 2006.

Fueglistaler, S. and Haynes, P. H.: Control of Interannual and Longer-Term Variability of Stratospheric Water Vapor, J. Geophys. Res., 110, D08107, doi:10.1029/2005JD006019, 2005.

Fueglistaler, S., Wernli, H., and Peter, T.: Tropical troposphereto-stratosphere transport inferred from trajectory calculations, J. Geophys. Res., 109, D03108, doi:10.1029/2003JD004069, 2004.

Fueglistaler, S., Bonazzola, M., Haynes, P. H., and Peter, T.: Stratospheric Water Vapor Predicted from the Lagrangian Temperature Histroy of Air Entering the Stratosphere in the Tropics, J. Geophys. Res., 110, D08107, doi:10.1029/2004JD005516, 2005.

Gettelman, A., Randel, W. J., Wu, F., and Massie, S. T.: Transport of water vapor in the tropical tropopause layer, Geophys. Res. Lett., 29, 1009, doi:10.1029/2001GL013818, 2002.

Gettelman, A. E. and Webster, C. R.: Simulations of Water Isotope Abundances in the Upper Troposphere and Lower Stratosphere and Implications for Stratosphere Troposphere Exchange, J. Geophys. Res., 110, D17301, doi:10.1029/2004JD004812, 2005.

Grosvenor, D. P., Choularton, T. W., Coe, H., and Held, G.: A Study of the Effect of Overshooting Deep Convection on the Water Content of the TTL and Lower Stratosphere from Cloud Resolving Model Simulations, Atmos. Chem. Phys., 7, 4977-5002, 2007 ,

http://www.atmos-chem-phys.net/7/4977/2007/.

Gunson, M. R., Abbas, M. M., Abrams, M. C., Allen, M., Brown, L. R., Brown, T. L., Chang, A. Y., Goldman, A., Irion, F. W., Lowes, L. L., Mahieu, E., Manney, G. L., Michelson, H. A., Newchurch, M. J., Rinsland, C. P., Salawitch, R. J., Stiller, G. P., Toon, G. C., Yung, Y. L., and Zander, R.: The Atmospheric Trace Molecule Spectroscopy (ATMOS) experiment: Deployment on the ATLAS Space Shuttle missions, Geophys. Res. Lett., 23, 2333-2336, 1996.

Hartmann, D. L., Holton, J. R., and Fu, Q.: The heat balance of the tropical tropopause, cirrus, and stratospheric dehydration, Geophys. Res. Lett., 28, 1969-1972, 2001.

Holton, J. R. and Gettelman, A.: Horizontal transport and the dehydration of the stratosphere, Geophys. Res. Lett., 28, 2799-2802, 2001.

Holton, J. R., Haynes, P. H., McIntyre, M. E., Douglass, A. R., Rood, R. B., and Pfister, L.: Stratosphere-troposphere exchange, Rev. Geophys., 33, 403-439, 1995.

Jensen, E. J. and Pfister, L.: Transport and Freeze-Drying in the Tropical Tropopause Layer, J. Geophys. Res., 109, D02207, doi:10.1029/2003JD004022, 2004.

Jensen, E. J., Pfister, L., Ackerman, A. S., and Tabazedeh, A.: A Conceptual Model of the Dehydration of Air Due to FreezeDrying by Optically Thin, Laminar Cirrus Rising Slowly Across the Tropical Tropopause, J. Geophys. Res., 106, 17 237-17 252, 2001.

Jensen, E. J., Smith, J. B., Pfister, L., Pittman, J. V., Weinstock, E. M., Sayres, D. S., Herman, R. L., Troy, R. F., Rosenlof, K., Thompson, T. L., A, M, F., Hudson, P. K., Cziczo, D. J., Heymsfield, A. J., Schmitt, C., and Wilson, J. C.: Ice Supersaturations Exceeding $100 \%$ at the Cold Tropical Tropopause: Implications for Cirrus Formation and Dehydration, Atmos. Chem. Phys., 5, 851-862, 2005, http://www.atmos-chem-phys.net/5/851/2005/.

Jensen, E. J., Ackerman, A. S., and Smith, J. A.: Can Overshooting Convection Dehydrate the Tropical Tropopause Layer?, J. Geophys. Res., 112, D11209, doi:10.1029/2006JD007943, 2007.

Johnson, D. G., Jucks, K. W., Traub, W. A., and Chance, K. V.: Isotopic composition of stratospheric water vapor: Implications for transport, J. Geophys. Res., 106, 12 219-12 226, 2001 a.

Johnson, D. G., Jucks, K. W., Traub, W. A., and Chance, K. V.: Isotopic composition of stratospheric water vapor: Measurements and Photochemistry, J. Geophys. Res., 106, 12 211-12217, $2001 b$.

Jouzel, J. and Merlivat, L.: Deuterium and Oxygen 18 in Precipitation: Modeling of the Isotopic Effects During Snow Formation, J. Geophys. Res., 99, 11 749-11 757, 1984.

Keith, D. W.: Stratosphere-troposphere exchange: Inferences from the isotopic composition of water vapor, J. Geophys. Res., 105, 15 167-15 173, 2000.

Koop, T., Ng, H. P., Molina, L. T., and Molina, M. J.: A New Optical Technique to Study Aerosol Phase Transitions: The Nucleation of Ice from $\mathrm{H}_{2} \mathrm{SO}_{4}$ Aerosols, J. Chem. Phys. A., 102, 8924-8931, 1998.

Kuang, Z., Toon, G. C., Wennberg, P. O., and Yung, Y. L.: Measured $\mathrm{HDO} / \mathrm{H}_{2} \mathrm{O}$ ratios across the tropical tropopause, Geophys. Res. Lett., 30, 1372, doi:10.1029/2003GL017023, 2003.

Lanzante, J. R., Klein, S. A., and Seidel, D. J.: Temporal Homogenization of Monthly Radiosonde Temperature Data. Part II: Trends, Sensitivities, and MSU Comparison, J. Climate, 16, 241$262,2003$.

Livesey, N. J.: Data Quality Document for the EOS MLS version 2.2 Level 2 Dataset, Tech. Rep. Tech. Rep., Jet Propulsion Laboratory, 2007.

Livesey, N. J., Froidevaux, L., Read, W. G., Lambert, A., Cofield, R. E., Fuller, R. A., Jarnot, R. F., Jiang, J. H., Jiang, Y. B., Knosp, B. W., Santee, M. L., Schwartz, M. J., Snyder, W. V., Stek, P. C., Wagner, P. A., Waters, J. W., Pumphrey, H. C., Avery, M., Browell, E. V., Christiensen, L. E., Loewenstein, M., 
Lopez, J. D., Sachse, G. W., and Webster, C. R.: Validation of EOS Microwave Limb Sounder $\mathrm{O}_{3}$ and $\mathrm{CO}$ observations in the upper troposphere / lower stratosphere, J. Geophys. Res., 113, D15S02, doi:10.1029/2007JD008805, in press, 2008.

Madden, R. A. and Julian, P. R.: Observations of the 40-50 Day Tropical Oscillation-A Review, Mon. Weather Rev., 122, 814837, 1994.

McFarquhar, G. M. and Heymsfield, A. J.: Parameterization of Tropical Cirrus Ice Crystal Size Distributions and Implications for Radiative Transfer: Results from CEPEX, J. Atmos. Sci., 54, 2187-2200, 1997.

Mote, P. W., Rosenlof, K. H., McIntyre, M. E., Carr, E. S., Gille, J. C., Holton, J. R., Kinnersley, J. S., Pumphrey, H. C., III, J. M. R., and Waters, J. W.: An atmospheric tape recorder: The imprint of tropical tropopause temperatures on stratospheric water vapor, J. Geophys. Res., 101, 3989-4006, 1996.

Mote, P. W., Dunkerton, T. J., McIntyre, M. E., Ray, E. A., Haynes, P. H., and III, J. M. R.: Vertical Velocity, Vertical Diffusion, and Dilution by Midlatitude Air in the Tropical Lower Stratosphere, J. Geophys. Res., 103, 8651-8666, 1998.

Moyer, E. J., Irion, F. W., Yung, Y. L., and Gunson, M. R.: ATMOS stratospheric water and implications for troposphericstratospheric transport, Geophys. Res. Lett., 23, 2385-2388, 1996.

Nassar, R., Bernath, P. F., Boone, C. D., Gettelman, A., McLeod, S. D., and Rinsland, C. P.: Variability in $\mathrm{HDO} / \mathrm{H}_{2} \mathrm{O}$ Abundance Ratios in the Tropical Tropopause Layer, J. Geophys. Res., 112, D21305, doi:10.1029/2007JD008417, 2007.

Nedoluha, G. E., Bevilacqua, R. M., Gomez, R. M., Siskind, D. E., Hicks, B. C., and III, J. M. R.: An evaluation of trends in middle atmospheric water vapor as measured by HALOE, WVMS, and POAM, J. Geophys. Res., 108, 4391, doi:10.1029/2002JD003332, 2003.

Notholt, J., Luo, B. P., Fueglistaler, S., Weisenstein, D., Rex, M., Lawrence, M. G., Bingemer, H., Wohltmann, I., Corti, T., Warneke, T., von Kuhlmann, R., and Peter, T.: Influence of Tropospheric $\mathrm{SO}_{2}$ Emissions on Particle Formation and the Stratospheric Humidity, Geophys. Res. Lett., 32, L07810, doi:10.1029/2004GL022159, 2005.

Pfister, L. and Jensen, E.: Convective Influence Calculations for CR-AVE and TC4, in: 14th Conference on Middle Atmosphere, American Meteorological Society, Portland Oregon, p. P3.12, 2007.

Pfister, L., Selkirk, H. B., Jensen, E. J., Schoeberl, M. R., Toon, O. B., Browell, E. V., Grant, W. B., Gary, B., Mahoney, M. J., Bui, T. V., and Hintsa, E.: Aircraft Observations of Thin Cirrus Clouds near the Tropical Tropopause, J. Geophys. Res., 106, 9765-9786, 2001.

Potter, B. E. and Holton, J. R.: The Role of Mesoscale Convection in the Dehydration of the Lower Tropical Stratosphere, J. Atmos. Sci., 52, 1034-1050, 1995.

Randel, W. J., Garcia, R. R., and Wu, F.: Time-Dependent Upwelling in the Tropical Lower Stratosphere Estimated from the Zonal-Mean Momentum Budget, J. Atmos. Sci., 59, 2141-2152, 2002.

Randel, W. J., Wu, F., Vömel, H., Nedoluha, G. E., and Forster, P.: Decreases in Stratospheric Water Vapor after 2001: Links to Changes in the Tropical Tropopause and the Brewer-Dobson Circulation, J. Geophys. Res., 111, D12312,
doi:10.1029/2005JD006744, 2006.

Randel, W. J., Park, M., Wu, F., and Livesey, N.: A Large Annual Cycle in Ozone above the Tropical Tropopause Linked to the Brewer-Dobson Circulation, J. Atmos. Sci., 64, 4479-4488, 2007.

Read, W. G., Wu, D. L., Waters, J. W., and Pumphrey, H. C.: Dehydration in the tropical tropopause layer: Implications from the UARS Microwave Limb Sounder, J. Geophys. Res., 109, D06110, doi:10.1029/2003JD004056, 2004.

Read, W. G., Shippony, Z., and Snyder, W. V.: The Clear-Sky Unpolarized Forward Model for the EOS Aura Microwave Limb Sounder (MLS), IEEE Transactions on Geosciences and Remote Sensing: The EOS Aura Mission, 44, 1367-1379, 2006.

Read, W. G., Bacmeister, J., Cofield, R. E., Cuddy, D. T., Daffer, W. H., Drouin, B. J., Fetzer, E., Froidevaux, L., Fuller, R., Herman, R., Jarnot, R. F., Jiang, J. H., Jiang, Y. B., Kelly, K., Knosp, B. W., Kovalenko, L. J., Lambert, A., Lay, R., Livesey, N. J., Liu, H.-C., Loo, M., Manney, G. L., Miller, D., Mills, B. J., Pickett, H. M., Pumphrey, H. C., Rosenlof, K. H., Sabounchi, X., Santee, M. L., Schwartz, M. J., Snyder, W. V., Stek, P. C., Su, H., Takacs, L. L., Thurstans, R. P., Vömel, H., Wagner, P. A., Waters, J. W., Weinstock, E. M., and Wu, D. L.: EOS Aura Microwave Limb Sounder Upper Tropospheric and Lower Stratospheric Humidity Validation, J. Geophys. Res., 112, D24S35, doi:10.1029/2007JD008752, 2007.

Read, W. G., Schwartz, M. J., Lambert, A., Su, H., Livesey, N. J., Daffer, W. H., and Boone, C. D.: The Roles of Convection, Extratropical Mixing, and In-Situ Freeze-drying in the Tropical Tropopause Layer, Atmos. Chem. Phys. Discuss., 8, 3961-4000, 2008 , http://www.atmos-chem-phys-discuss.net/8/3961/2008/.

Rodgers, C. D.: Characterization and Error Analysis of Profiles Retrieved From Remote Sounding Measurements, J. Geophys. Res., 95, 5587-5595, 1990.

Rosenlof, K. H.: Seasonal Cycle of the Residual Mean Meridional Circulation in the Stratosphere, J. Geophys. Res., 100, 51735191, 1995.

Rosenlof, K. H. and Reid, G. C.: Trends in the Temperature and Water Vapor Content of the Tropical Lower Stratosphere: The Sea-Surface Connection, J. Geophys. Res., 113, D06107, doi:10.1029/2007JD009109, 2008.

Rosenlof, K. H., Oltmans, S. J., Kley, D., III, J. M. R., Chiou, E.W., Chu, W. P., Johnson, D. G., Kelly, K. K., Michelsen, H. A., Nedoluha, G. E., Remsberg, E. E., Toon, G. C., and McCormick, M. P.: Stratospheric water vapor increases over the past halfcentury, Geophys. Res. Lett., 28, 1195-1198, 2001.

Scherer, M., Vömel, H., Fueglistaler, S., Oltmans, S. J., and Staehelin, J.: Trends and Variability of Midlatitude Stratospheric Water Vapor Deduced from the Re-evaluated Boulder Balloon Series and HALOE, Atmos. Chem. Phys., 8, 1390-1402, 2008, http://www.atmos-chem-phys.net/8/1390/2008/.

Schmidt, G. A., Hoffmann, G., Shindell, D. T., and Hu, Y.: Modeling Atmospheric Stable Water Isotopes and the Potential for Constraining Cloud Processes and StratosphereTroposphere Water Exchange, J. Geophys. Res., 110, D21314, doi:10.1029/2005JD005790, 2005.

Schoeberl, M. R., Duncan, B. N., Douglass, A. R., Waters, J., Livesey, N., Read, W., and Filipiak, M.: The Carbon Monoxide Tape Recorder, Geophys. Res. Lett., 33, L12811, 
doi:10.1029/2006GL026178, 2006.

Schoeberl, M. R., Ziemke, J. R., Bojkov, B., Livesey, N., Duncnan, B., Strahan, S., Froidevaux, L., Kulawik, S., Bhartia, P. K., Chandra, S., Levelt, P. F., Witte, J. C., Thompson, A. M., Cuevas, E., Redondas, A., Tarasick, D. W., Davis, J., Bodeker, G., Hansen, G., Johnson, B. J., Oltmans, S. J., Vömel, H., Allaart, M., Kelder, H., Newchurch, M., Godin-Beekmann, S., Ancellet, G., Claude, H., Andersen, S. B., Kyrö, E., Parrondos, M., Yela, M., Zablocki, G., Moore, D., Dier, H., von der Garthen, P., Viatte, P., Stübi, R., Calpini, B., Skrivankova, P., Dorokhov, V., de Backer, H., Schmidlin, F. J., Coetzee, G., Fujiwara, M., Thouret, V., Posny, F., Morris, G., Merrill, J., Leong, C. P., Koenig-Langlo, G., and Joseph, E.: A trajectory-based estimate of the tropospheric ozone column using the residual method, J. Geophys. Res., 112, D24S49, doi:10.1029/2007JD008773, 2007.

Schwartz, M. J., Lambert, Manney, G. L., Read, W. G., Livesey, N. J., Froidevaux, L., Ao, C. O., Bernath, P. F., Boone, C. D., Cofield, R. E., Daffer, W. H., Drouin, B. J., Fetzer, E. J., Fuller, R. A., Jarnot, R. F., Jiang, J. H., Jiang, Y. B., Knosp, B. W., Kruger, K., Li, J.-L. F., Mlynczak, M. G., Pawson, S., III, J. M. R., Santee, M. L., Snyder, W. V., Stek, P. C., Thurstans, R. P., Tompkins, A. M., Wagner, P. A., Walker, K. A., Waters, J. W., and $\mathrm{Wu}, \mathrm{D}$. L.: Validation of the Aura Microwave Limb Sounder Temperature and Geopotential Height Measurements, J. Geophys. Res., 113, D15S11, doi:10.1029/2007JD008783, 2008.

Seidel, D. J., Fu, Q., Randel, W. J., and Reichler, T. J.: Widening of the Tropical Belt in a Changing Climate, Nature Geoscience, 1, 21-24, doi:10.1038/ngeo.2007.38, 2 December 2007.

Sherwood, S. C.: A microphysical connection among biomass burning, cumulus clouds, and stratospheric moisture, Science, 295, 1272-1275, 2002.

Sherwood, S. C. and Dessler, A. E.: On the control of stratospheric humidity, Geophys. Res. Lett., 27, 2513-2516, 2000.

Sherwood, S. C. and Dessler, A. E.: A model for transport across the tropical tropopause, J. Atmos. Sci., 58, 765-779, 2001.

Sherwood, S. C. and Dessler, A. E.: Convective mixing near the tropical tropopause: insights from seasonal variations, J. Atmos. Sci., 60, 2674-2685, 2003.

Smith, J. A., Ackerman, A. S., Jensen, E. J., and Toon, O. B.: Role of Deep Convection in Establishing the Isotopic Composition of Water Vapor in the Tropical Transition Layer, Geophys. Res. Lett., 33, L06812, doi:10.1029/2005GL024078, 2006.
Staniforth, A. and Côté, J.: Semi-Langrangian Integration Schemes for Atmospheric Models-A Review, Mon. Weather Rev., 119, 2206-2223, 1991.

Wang, P.-H., Minnis, P., McCormick, M. P., Kent, G. S., and Skeens, K. M.: A 6-year climatology of cloud occurrence frequency from Stratospheric Aerosol and Gas Experiment II observations (1985-1990), J. Geophys. Res., 101, 29407-29429, 1996.

Waters, J. W., Froidevaux, L., Harwood, R. S., Jarnot, R. F., Pickett, H. M., Read, W. G., Siegel, P. H., Cofield, R. E., Filipiak, M. J., Flower, D. A., Holden, J. R., Lau, G. K., Livesey, N. J., Manney, G. L., Pumphrey, H. C., Santee, M. L., Wu, D. L., Cuddy, D. T., Lay, R. R., Lou, M. S., Perun, V. S., Schwartz, M. J., Stek, P. C., Thurstans, R. P., Boyles, M. A., Chandra, K. M., Chavez, M. C., Chen, G.-S., Chudasama, B. V., Dodge, R., Fuller, R. A., Girard, M. A., Jiang, J. H., Jiang, Y., Knosp, B. W., LaBelle, R. C., Lam, J. C., Lee, K. A., Miller, D., Oswald, J. E., Patel, N. C., Pukala, D. M., Quintero, O., Scaff, D. M., Snyder, W. V., Tope, M. C., Wagner, P. A., and Walch, M. J.: The Earth Observing System Microwave Limb Sounder (EOS MLS) on the Aura satellite, IEEE T. Geosci. Remote Sens., The EOS Aura Mission, 44, 1075-1092, 2006.

Webster, C. R. and Heymsfield, A. J.: Water isotope ratios D/H, ${ }^{18} \mathrm{O} /{ }^{16} \mathrm{O},{ }^{17} \mathrm{O} /{ }^{16} \mathrm{O}$ in and out of clouds reveal dehydration pathways and the origin of cirrus, Science, 302, 1742-1745, 2003.

Wong, S. and Dessler, A. E.: Regulation of $\mathrm{H}_{2} \mathrm{O}$ and $\mathrm{CO}$ in the Tropical Tropopause Layer by the Madden-Julian Oscillation, J. Geophys. Res., 112, D14305, doi:10.1029/2006JD007940, 2007.

Wu, D. L., Preusse, P., Eckermann, S., Jiang, J., de la Torre Juarez, M., Coy, L., and Wang, D.: Remote Sounding of Atmospheric Gravity Waves with Satellite Limb and Nadir Techniques, Adv. Space Res., 37, 2269-2277, 2006.

Zhang, G. J. and McFarlane, N. A.: Sensitivity of climate simulations to the parameterization of cumulus convection in the Canadian Climate Centre General Circulation Model, Atmos. Ocean., 33, 407-446, 1995.

Zhou, X.-L., Geller, M. A., and Zhang, M.: Cooling Trend of the Tropical Cold Point Tropopause Temperatures and its Implications, J. Geophys. Res., 106, 1511-1522, 2001. 